\title{
Article \\ Sovereign Exposures of European Banks: It Is Not All Doom
}

\author{
Martien Lamers (D), Thomas Present*(D) and Rudi Vander Vennet (D) \\ Department of Economics, Ghent University, Sint-Pietersplein 5, 9000 Ghent, Belgium; \\ martien.lamers@ugent.be (M.L.); rudi.vandervennet@ugent.be (R.V.V.) \\ * Correspondence: thomas.present@ugent.be
}

\begin{abstract}
We investigate whether sovereign bond holdings of European banks are determined by a risk-return trade-off. Using data between 2011 and 2018 for 75 European banks, we confirm that banks exhibited risk-taking behavior during the sovereign debt crisis, e.g., due to moral suasion. In the period 2015-2018, however, banks' investments in sovereign bonds are characterized by sound risk-return considerations, suggesting a lessening of the doom loop. This result is mainly driven by banks in the core European countries, as banks in the GIPS countries do not exhibit such behavior, nor do they avoid riskier bonds following the sovereign debt crisis.
\end{abstract}

Keywords: sovereign exposures; risk-return trade-off; bank-sovereign nexus; doom loop; Sharpe ratio

JEL Classification: G11; G18; G21; G28

check for

updates

Citation: Lamers, Martien, Thomas Present, and Rudi Vander Vennet.

2022. Sovereign Exposures of

European Banks: It Is Not All Doom. Journal of Risk and Financial

Management 15: 69. https://doi.org/

10.3390/jrfm15020069

Academic Editor: Pierluigi Murro

Received: 4 January 2022

Accepted: 26 January 2022

Published: 3 February 2022

Publisher's Note: MDPI stays neutral with regard to jurisdictional claims in published maps and institutional affiliations.

Copyright: (c) 2022 by the authors Licensee MDPI, Basel, Switzerland. This article is an open access article distributed under the terms and conditions of the Creative Commons Attribution (CC BY) license (https:// creativecommons.org/licenses/by/ $4.0 /)$.

\section{Introduction}

In this paper, we investigate whether or not observed changes in the composition of the sovereign bond portfolios of European banks are determined by a risk-return tradeoff. The average European bank holds 15 percent of its assets in the form of securities, of which sovereign bonds constitute the main category. Next to their natural role as liquid investments, sovereign bonds possess a number of advantages for European banks. Member States' bonds carry a zero-risk weight in the calculation of capital requirements, high-quality (sovereign) bonds are eligible for compliance with the Liquidity Coverage Ratio (LCR) rules, and these bonds serve as collateral for access to the ECB's regular refinancing operations as well as the longer-term refinancing operations (LTRO) programs. However, banks have been accused to disproportionately invest in bonds issued by their home sovereign, especially in periods of sovereign stress (see, e.g., Horvath et al. 2015). It is argued that some banks built up excessive exposures, thereby creating a 'doom loop' between European banks and their sovereigns and exacerbating the risk of contagion between sovereigns and banks (see, e.g., Acharya et al. 2014; Brunnermeier et al. 2016; Caselli et al. 2016; De Bruyckere et al. 2013; Farhi and Tirole 2018; Fratzscher and Rieth 2019; Stângă 2014).

Existing literature has proposed several hypotheses to explain why banks allocate their holdings into certain sovereign bonds: banks may search for yields or engage in carry-trade behavior (Acharya and Steffen 2015; Altavilla et al. 2017), banks may have been subject to moral suasion by their home sovereign during periods of sovereign distress (De Marco and Macchiavelli 2016; Horvath et al. 2015; Ongena et al. 2019), or they can engage in flight-to-safety actions (Buch et al. 2016). Faced with the consequences of the doom loop, regulators and supervisors have proposed approaches to tackle the sovereign-bank nexus by, e.g., imposing capital requirements on sovereign bond holdings or implementing diversification obligations in the sovereign bond portfolios of banks (Alogoskoufis and Langfield 2020; Lenarcic et al. 2016). Such regulation could potentially change banks' motives to invest in certain sovereign bonds, and force banks to return to 'rational' behavior in which return and risk are balanced. This paper analyzes whether or not bank sovereign 
bond investments in the period following the sovereign debt crisis are indeed compatible with a rational risk-return trade-off.

Dealing with risk-return considerations, also in sovereign bond portfolios, has become even more important since the sovereign debt crisis in Europe. In the period before the crisis, banks and other investors generally considered sovereign bonds as risk-free investments. Apart from a small default risk premium related to the rating or a small liquidity premium, the spreads of most sovereign bonds compared to the German Bund benchmark were of a low magnitude. However, the sovereign debt crisis showed that bonds of distressed countries do carry counterparty risk since the bonds of the countries later indicated as GIPS (Greece, Italy, Portugal, and Spain) exhibited widening spreads, requiring forceful action by the ECB and, in some cases, a bailout organized by the European Financial Stability Facility (EFSF) and, later, the European Stability Mechanism (ESM). Moreover, the search for yield or carry-trade in which some banks were involved backfired, e.g., Dexia bank had to be bailed out a second time in 2012, partly because of its excessive exposure to Greek bonds (Acharya and Steffen 2015). Additionally, political events may lead to the resurfacing of a sovereign risk premium in countries deemed at risk. The case of Italy is considered as a prominent example, since political uncertainty and the threat of non-compliance with the European budgetary framework prompted bond investors to require a substantial risk premium in certain episodes. Such experiences should incentivize banks to diversify their sovereign exposures in order to avoid costly fire-sale losses. Hence, banks should not only focus on return but also take into account the risk dimension. The question we address is whether or not European banks' sovereign bond portfolios are compatible with a rational risk-return trade-off in the period following the sovereign debt crisis. Deviations from such behavior may justify the introduction of rules aiming to reduce portfolio risk or imposing diversification.

To perform our analysis, we use data on sovereign bond holdings from the transparency exercises, capital exercises, and stress tests performed by the European Banking Authority (EBA) between 2011 and 2018. From these exercises, we obtain data on the stock of sovereign exposures of the largest 75 European banks to 22 EU sovereigns at a semi-annual frequency. We investigate the motives for why banks decide to increase or decrease their exposure to the sovereign debt of EU member states, and specifically focus on the risk-return trade-off of sovereign bonds. The risk-return trade-off is captured in several ways; our primary focus is on the Sharpe ratio and its components, but we also consider the yield to maturity of the bonds as well as sovereign CDS spreads. In order to control for unobserved bank or sovereign heterogeneity, we progressively saturate the model with bank-time fixed effects, country fixed effects, and bank-country fixed effects. This allows us to disentangle the return and risk drivers of sovereign bond investments by the banks, and control for ulterior motives previously documented in the literature.

For the period 2011-2014, our estimations confirm the finding in the existing literature that banks were subject to moral suasion as they predominantly invested in bonds of their home sovereign. However, in the period 2015-2018, banks' investments and divestments of sovereign bonds are characterized by sound risk-return considerations, which we capture with the Sharpe ratio, suggesting a lessening of the doom loop. Hence, even in a period of declining interest rates caused by the ECB's asset purchase program, banks move away from excessive risk-taking in their sovereign bond portfolios. Interestingly, when we split the banks and their investments into GIPS and non-GIPS countries, we find that the result in the period following the sovereign debt crisis is driven mainly by banks in the non-GIPS countries. Investments from banks in the non-GIPS countries load significantly and positively on the Sharpe ratios of both GIPS and non-GIPS sovereign bonds after the sovereign debt crisis, but not before. However, GIPS country banks are not found to exhibit a sound risk-return trade-off in their sovereign securities investments, nor do they avoid securities of riskier countries, in the period following the sovereign debt crisis. In other words, those banks which were already most exposed to the bank-sovereign doom loop show no signs of improvement. Once the public-sector purchase program of the ECB stops, this may feed policy discussions about excessive sovereign exposures of certain 
banks and may weigh on further steps to complete the European Banking Union by, e.g., implementing a European deposit insurance system.

Our results are robust, using different measures of exposures, different measures of risk-return trade-off, and taking into account different accounting treatments.

The analysis in this paper contributes to the prolific literature on the bank-sovereign risk-nexus in Europe (see, e.g., Acharya et al. 2014; Farhi and Tirole 2018; Gennaioli et al. 2014). We investigate the entire post-2011 period, rather than focusing on specific episodes, such as LTRO allocations or the Quantitative Easing (QE) era, or on subsets of banks, as is done in, e.g., moral suasion papers dealing with banks from distressed countries. Moreover, we exploit the full set of regulatory disclosures on sovereign bond holdings in the framework of the stress tests and transparency exercises conducted by the EBA. The findings contribute to the policy discussion of the appropriate measures to tackle excessive bond concentrations in European banks. Our paper is also related to the portfolio allocation literature pioneered by Markowitz (1952), and, for example, analyzed in the context of mutual fund managers by Daniel et al. (1997) and Kacperczyk et al. (2005). In this paper, we focus on investment decisions of a different type of investor (banks) with a specific universe of investments (sovereign bonds). Therefore, the paper is also related to the literature analyzing the return commonalities in sovereign bonds, such as Pilotte and Sterbenz (2006); Leote de Carvalho et al. (2014); Fontana and Scheicher (2016); and Zaremba and Czapkiewicz (2017), who find evidence of low-risk anomalies in government bonds and strong momentum effects in their returns.

The rest of the paper is organized as follows. In Section 2, we elaborate on the motivation and hypotheses. In Sections 3 and 4, we discuss our methodology and data, followed by the results in Section 5 and robustness tests in Section 6, before we conclude in Section 7.

\section{Motivation and Hypotheses}

Banks have, for a long time, occupied a dominant position in the sovereign debt markets. Although other institutional investors, such as pension funds, have gained prominence, banks remain important holders of sovereign securities. Typically, banks are expected to hold diversified portfolios of sovereign securities, both in terms of maturities and geographical composition. Yet, as in the case of other types of securities, there is a well-documented tendency towards home bias in bond holdings (Coeurdacier and Rey 2013). In Euro-Area countries, banks frequently hold between 20 percent and 30 percent of the outstanding debt of the domestic sovereign in normal times (Lenarcic et al. 2016). In some periods, typically associated with sovereign stress, banks have increased their exposures to the home sovereign. This was especially visible during the sovereign debt crisis in the Euro Area. Moreover, the large liquidity injections (LTRO) by the ECB aimed at restoring the liquidity of the banking system, caused a build-up of domestic sovereign exposures, especially in peripheral countries (Crosignani et al. 2020).

Regulators are aware that the tight linkage between sovereign and bank balance sheets magnified the severity of the European sovereign debt crisis. As a consequence, reform efforts have been undertaken at the institutional level. The bail-in requirement in the Bank Recovery and Resolution Directive (BRRD), in principle, renders bailout by the sovereign impossible, replacing it with a mandatory bail-in of private creditors. In the framework of the Banking Union, mechanisms for the orderly unwinding of systemic banks have been introduced, to be administered by the Single Resolution Board. Simultaneously, backstop mechanisms such as a Single Resolution Fund and an ESM loan facility for bank sector restructuring have been established. Yet, no regulatory measures to constrain sovereign exposures at the bank level have yet been enacted. Several proposals have been launched, such as the introduction of a non-zero weighting scheme for sovereign securities for the calculation of bank capital requirements and the imposition of limits for sovereign exposures (Lenarcic et al. 2016). The objective of such measures would be to incentivize banks to diversify their sovereign bond holdings away from the domestic sovereign. 
Existing literature has documented several reasons why banks concentrate their holdings into certain sovereign bonds. First, banks may engage in risk-shifting or engage in a search for yields, as shown in Altavilla et al. (2017), who find that poorly capitalized periphery banks increased their holdings of high-yielding (periphery) sovereign bonds in and following the sovereign debt crisis. Similarly, Acharya and Steffen (2015) report that banks' stock returns load positively on high-yielding periphery bond returns and negative on low-yielding German government bonds, thereby generating a carry-trade. Second, banks might face pressure from their home sovereigns to purchase new debt, especially if these banks have been bailed out by their sovereign. The existence of this moral suasion has been demonstrated in, amongst others, Horvath et al. (2015); De Marco and Macchiavelli (2016); Altavilla et al. (2017); and Ongena et al. (2019). Finally, banks can engage in flights-to-safety, as observed by Buch et al. (2016), who found that German banks, on average, reduced sovereign debt holdings of high-yield sovereigns between 2008 and 2010.

Due to the arguments stipulated above, banks' holdings of sovereign bonds might be biased in periods of stress. Our hypothesis is that diversification based on a sound risk-return trade-off should be the natural investor behavior of banks in sovereign bond investments and, hence, banks would revert to this behavior after the period of the sovereign debt crisis. Why would banks diversify their sovereign bond holdings? There are regulatory motives as well as economic considerations.

On the regulatory front, several mechanisms are at play. First, banks need to maintain adequate liquidity in order to withstand shocks in deposit or other funding markets. Supervisors monitor the liquidity position of banks, and government securities are an important source of (secondary) liquidity because they can be sold easily in secondary markets. In the post-crisis period, the liquidity rules have been strengthened by Basel III in the form of a liquidity coverage ratio (LCR). The LCR obliges banks to hold sufficient high-quality liquid assets (HQLA), and sovereign securities constitute the main part of these HQLA. Since a substantial fraction of banks had to build up their HQLA in order to comply with the gradual monitoring and later enforcement of the LCR, acquiring a diversified portfolio of eligible sovereign bonds was necessary for European banks. Second, banks need to comply with stricter capital regulations under Basel III, which forces them to manage the risk profile of their assets. Government bonds are a straightforward investment class to adapt the risk-weighted assets when a bank becomes capital constrained. Lenarcic et al. (2016) argue that restructuring bank assets towards holding more sovereign bonds alleviated capital pressure and allowed some banks to comply with the new rules without resorting to more expensive capital raising or engaging in deleveraging. Third, rational banks may anticipate rulemaking in the area of sovereign concentration. Policymakers agree that completing the Banking Union is important not only for severing the link between banks and sovereigns but also to establish a pan-European banking market and stimulate cross-border bank consolidation. However, several countries, especially some of the core countries of the Euro Area, have made it clear that a common deposit guarantee fund, which is the necessary third pillar of such a Banking Union (next to supervision and resolution), is only politically feasible when bank risk is sufficiently contained. Therefore, all policy initiatives aimed at completing the Banking Union contain proposals to limit concentrated exposures of banks to sovereigns by implementing exposure limits or capital charges (see e.g., Bénassy-Quéré et al. 2018). Similarly, regulators and bank supervisors have issued repeated recommendations to banks to lower their domestic bond exposures and diversify their sovereign bond portfolios (Enria 2019; Enria et al. 2016). As a result, banks have the incentive to diminish large exposures to their home or other sovereigns in anticipation of explicit restrictions. Hence, diversification would be a rational anticipation of the future regulatory environment. 
Next to complying with regulatory constraints, diversification also has a solid economic rationale. First, sovereign securities are essential assets in the banks' management of their capital adequacy and liquidity profile. The securities of most European sovereigns are considered as low risk; hence, they can be used to de-risk the balance sheet and aid banks in complying with Basel-type risk-weighted capital ratios. Kirschenmann et al. (2020) report that the 'sovereign subsidy', in terms of reduced capital needs, was substantial for European banks. Government securities are also the most important asset class used as collateral in refinancing operations with the central bank in the form of repurchase agreements. Since banks need constant access to interbank borrowing and to the facilities offered by the ECB, maintaining a diversified pool of government bonds is essential for securing such access.

Second, when considered from a risk perspective, more diversification of sovereign exposures would make banks more resilient to shocks in the credit quality of sovereigns. In the recent past, gambling has backfired. Some banks which had engaged in carry-trade behavior (see Acharya and Steffen 2015) failed subsequently, and were only rescued with costly bailouts, causing public discontent. In addition, political events may cause the resurfacing of a sovereign risk premium in sovereign bond yields. Such cases should incentivize banks to diversify their sovereign exposures in order to avoid fire-sale losses. Hence, banks may use the composition of their sovereign holdings as a signaling device to market participants about their risk profile. This feature has gained prominence since the EBA regularly publishes the sovereign exposures of systemic European banks in the framework of its stress tests and transparency exercises. If better sovereign bond portfolio diversification improves the perceived risk profile of the banks, it may also lead to lower funding costs. Hence, as important government bond investors, banks have clear economic incentives to apply a risk-return trade-off in the management of their sovereign portfolio.

The motives for banks to hold a diversified sovereign bond portfolio lead to the following hypotheses that we investigate in the empirical analysis. The main hypothesis is that banks will apply a risk-return trade-off in the management of their sovereign bond portfolio. We expect sovereign bond investments to be positively related to the Sharpe ratio, which is a common metric to capture the risk-return trade-off in asset allocation decisions. In terms of return, the hypothesis is that increases in sovereign bond exposures will be positively affected by the bonds' return, but only when they are not associated with higher bond risk, measured as the standard deviation of bond returns over the investment horizon. Finally, the hypothesis of risk reduction conjectures that bank bond investments should be associated with lower bond risk or lower sovereign CDS spreads, consistent with banks divesting exposures to high-risk sovereigns. As the existing literature has already documented deviations from this behavior in periods of sovereign stress, we are mainly interested in whether banks have shifted to rational investor behavior in the period following the sovereign debt crisis, driven by regulatory and economic rationales. If this hypothesis stands up to empirical scrutiny, this would have implications for the appropriate regulatory approach to the issue of bank-sovereign links.

\section{Methodology}

Our model for exposure to sovereign debt follows that of, e.g., Ongena et al. (2019), and investigates whether banks are more likely to purchase bonds with a better risk-return trade-off in the period following the sovereign debt crisis. Specifically, we estimate the following specification for our two subperiods:

$$
\Delta \operatorname{Exp}_{i, s, t}=\beta_{1} \text { Risk-return trade-off } f_{s, t}+\beta_{2} X_{i, t}+\beta_{3} \varphi_{s}+\beta_{4} \mu_{i}+\beta_{5} \tau_{t}+\epsilon_{i, s, t}
$$

where $\Delta \operatorname{Exp}_{i, s, t}$ is defined as the (change in) exposure to bonds of sovereign $s$, by bank $i$, at time $t$. Risk-return trade-off $f_{s, t}$ is a measure for the risk-return reward attached to a bond and is captured by either the Sharpe ratio, its components (the return and volatility), or the bond's yield-to-maturity. $X_{i, t}$ is a matrix of time-varying bank-specific control variables; $\varphi_{s}$, $\mu_{i}$ and $\tau_{t}$ are country-, bank-, and time-fixed effects; $\epsilon_{i, s, t}$ is an i.i.d. error term. 
Our main coefficient of interest is $\beta_{1}$. This coefficient captures the extent to which Risk-return trade-off $f_{s, t}$, captured at the level of the sovereign bond $s$ at time $t$, is a determinant of the bank's net purchasing decision. If $\beta_{1}$ is not significant, banks' purchasing behavior could be driven by ulterior motives. Since previous literature has found that European banks engaged in strategies consistent with a search for yields, carry-trading, and moral suasion, we expect that, in the period of the sovereign debt crisis, $\beta_{1}$ will not be significant. However, if banks' purchasing behavior changed in the period after the sovereign debt crisis, characterized by the ECB asset purchase program and potential new regulation on sovereign bond holdings, and is driven by rational investor considerations, $\beta_{1}$ will be positive and statistically significant.

To test whether $\beta_{1}$ became significant after the period of the sovereign debt crisis, we divide our sample in 2 periods and estimate Equation (1) in each period separately. The first period, between 2011 and 2014, is dominated by the sovereign crisis during which the bank-sovereign nexus became apparent, e.g., through bank and sovereign CDS spreads moving in tandem. In this period, the ECB undertook actions to lessen the doom loop, e.g., the Outright Monetary Transactions (OMT) program following the Draghi 2012 'whatever it takes' speech was intended to restore the transmission of monetary policy across the Euro Area and lower the bond yield spreads of the vulnerable countries. However, the provision of additional liquidity to banks via LTROs may have provided the opportunity for banks to increase their holdings of government bonds. There is evidence that banks have used LTRO funding to increase their exposure to domestic sovereign bonds during that period, especially in the peripheral countries (Carpinelli and Crosignani 2021; Crosignani et al. 2020).

The second period covers the years between 2015 and 2018, the period during which several regulatory and supervisory events may have altered the banks' investment behavior in a structural way. On the one hand, the Bank Recovery and Resolution Directive, which was decided and introduced in 2014-2015, is designed to tackle the bank-sovereign doom loop by establishing a framework for the orderly resolution of banks through bail-in, as opposed to the government bailouts during the banking crisis. The fact that even large banks can no longer rely on government support may alter their risk appetite in general and, more specifically, may induce banks to buy fewer domestic sovereign bonds. In November 2014, the ECB became responsible for the supervision of systemic banks in the Eurozone. The Comprehensive Assessment that preceded this transfer of bank supervision already indicated that the ECB would be a tougher supervisor than the national authorities. The regulatory suasion of the ECB may have prompted the banks to review their risk profile, including their sovereign bond investment behavior. On the other hand, in the same period, the ECB implemented its public sector asset purchase program. The explicit objective of this program was to lower long-term interest rates and thereby promote bank lending to the real economy. However, a period of decreasing long-term yields may induce the banks to display search-for-yield behavior. Bubeck et al. (2020) show that the ECB's negative interest rate policy induced systemic banks to invest more in higher yielding, and hence, riskier, private securities. ${ }^{1}$ Since we estimate Equation (1) on this period, we can identify which channel empirically dominates the other.

We add several commonly used bank business model characteristics as bank control variables $X_{i, t}$ as certain bank types might be more inclined to purchase more risky bonds. To avoid problems with endogeneity of the bank controls and since these controls are only slowly varying over time, we lag all bank controls by one period. To further control for bank and sovereign heterogeneity, we include a set of fixed effects. With the country $\left(\varphi_{s}\right)^{-}$, bank $\left(\mu_{i}\right)^{-}$, and time $\left(\tau_{t}\right)$-fixed effects, we control for country-specific, bank-specific, and time-specific determinants in purchasing behavior. However, since our dataset is three-dimensional in nature, we can also include pairwise fixed effects. For instance, with bank-time $\mu_{i, t}$-fixed effects, we analyze whether the same bank at the same point in time exhibits higher net purchases of bonds with a better risk-return trade-off, using only the variation across sovereign bonds at the same point in time. Similarly, when using bank-country-fixed effects, we control for the fact that certain banks have preferences to purchase bonds of a certain sovereign (for instance due to home bias or the geographical 
network of the bank). Finally, we include in all regressions a home dummy variable to capture deviating behavior of banks when investing in the domestic sovereign, for reasons such as moral suasion described in Section 2, potential sovereign-based rating caps, or an anticipated bank tax (Dermine 2020).

\section{Data}

To test whether banks' sovereign bond holdings are determined by a risk-return tradeoff, we require data on bank sovereign bond holdings, the risk-return properties of these bonds, and bank-specific information to control for differences in purchasing behavior across banks. We collect these data from several sources.

\subsection{Sovereign Bond Holdings}

Data on the sovereign bond holdings of banks are obtained from the European Banking Authority (EBA), capital exercises, stress tests, and transparency exercises. From this database, we obtain the gross carrying amount of sovereign debt for each bank-sovereign combination. $^{2}$ The data is reported at a semiannual frequency and spans the period from 2011:H2 to 2018:H1 with a data gap at 2014:H1. Moreover, for 2015:H2, there is an overlap between the transparency exercise and the stress test conducted in 2016. Since the transparency exercises are reported at more regular intervals compared to the stress test, we use the data from the transparency exercise to ensure consistency over time.

Data on sovereign bond holdings is used to measure the (change in) net exposure in four different ways, each capturing different considerations regarding the asset allocation within a bank's sovereign portfolio. First, following Ongena et al. (2019), we measure the change in holdings of bank $i$ in sovereign $s$ between time $t$ and $t-1$ as a percentage of the total sovereign debt portfolio of the bank at time $t-1$ :

$$
\Delta \operatorname{Exp}_{i, s, t}^{A}=\frac{\operatorname{Exp}_{i, s, t}-\operatorname{Exp}_{i, s, t-1}}{\sum_{s=1}^{S} \operatorname{Exp}_{i, s, t-1}},
$$

which captures the increase in the sovereign exposure relative to the size of the total sovereign debt portfolio of a bank. As such, it reflects the within-sovereign portfolio asset allocation of banks. ${ }^{3}$

While the measure in Equation (2) is our preferred one, in Section 6, we also test different definitions of the main variable. The second measure is similar to Altavilla et al. (2017), and is the percentage change in sovereign bond holdings at the bank-sovereign level:

$$
\Delta \operatorname{Exp}_{i, s, t}^{B}=\ln \left[\frac{\operatorname{Exp}_{i, s, t}}{\operatorname{Exp}_{i, s, t-1}}\right],
$$

representing the within-exposure asset allocation of banks. ${ }^{4}$

Our third measure is the change in weight that the sovereign exposure has in the total sovereign debt portfolio of the bank between time period $t$ and period $t-1$ :

$$
\Delta \operatorname{Exp}_{i, s, t}^{C}=\frac{\operatorname{Exp}_{i, s, t}}{\sum_{s=1}^{S} \operatorname{Exp}_{i, s, t}}-\frac{\operatorname{Exp}_{i, s, t-1}}{\sum_{s=1}^{S} \operatorname{Exp}_{i, s, t-1}},
$$

capturing to what extent the weights in the portfolio change between $t-1$ and $t$.

Finally, while the previous three measures capture the intensive margin, we also test whether the extensive margin of banks' purchasing behavior is changed in the period after the sovereign debt crisis by creating an indicator variable that takes on a value -1 when a bank divests from the sovereign, a value of 1 when a bank chooses to invest in the sovereign, or 0 if the bank chooses neither to invest or divest: 


$$
\Delta \operatorname{Exp}_{i, s, t}^{E x t}=\left\{\begin{aligned}
-1, & \text { if } \operatorname{Exp}_{i, s, t}-\operatorname{Exp}_{i, s, t-1}<0 \\
0, & \text { if } \operatorname{Exp}_{i, s, t}-\operatorname{Exp}_{i, s, t-1}=0 . \\
1, & \text { if } \operatorname{Exp}_{i, s, t}-\operatorname{Exp}_{i, s, t-1}>0
\end{aligned}\right.
$$

Note that Equation (5) does not take into account the relative size of the investment or divestment, as it focuses only on whether a bank chooses to increase, decrease, or not change its holdings in a particular sovereign.

Our preferred measure of the change in exposure is $\Delta \operatorname{Exp}_{i, s, t}^{A}$ in Equation (2). For a bank with a total sovereign portfolio of EUR 100 million at $t-1$, an increase for one of its sovereign exposures from EUR 2 million at time $t-1$ to EUR 4 million at time $t$ would be registered as a 2-percent increase in the exposure to that country using Equation (2). While the other measures are relevant to capturing the asset allocation decisions of banks, we need to be careful with the interpretation of $\Delta \operatorname{Exp}_{i, s, t}^{B}$ and $\Delta \operatorname{Exp}_{i, s, t}^{C}$ in Equations (3) and (4), as these give the same weight to large and small exposure increases. For instance, the increase in a sovereign exposure from EUR 2 million to EUR 4 million would be registered as a 100-percent increase using $\Delta \operatorname{Exp}_{i, s, t}^{B}$, even though the exposure only accounts for around 4 percent of the new sovereign bond portfolio. Similarly, using $\Delta E x p_{i, s, t}^{C}$ in Equation (4) would also lead the increase to be registered as a 2-percent increase in the exposure to that country, but, ceteris paribus, it would also decrease the exposure to all other sovereigns as their weight in the portfolio at time $t$ goes down. Table 1 gives an illustration of how the different measures are altered under a few hypothetical situations. ${ }^{5}$ In our main analyses, we use $\Delta E x p_{i, s, t}^{A}$ from Equation (2), but we also run robustness tests with the other measures $\Delta \operatorname{Exp}_{i, s, t}^{B}, \Delta \operatorname{Exp}_{i, s, t}^{C}$ and $\Delta \operatorname{Exp}_{i, s, t}^{E x t}$ in Section 6.

Table 1. Illustration of different exposure measures.

\begin{tabular}{|c|c|c|c|c|c|c|c|c|}
\hline \multicolumn{9}{|c|}{ Increase: } \\
\hline$E x p_{t-1}$ & $E x p_{t}$ & $\Delta \operatorname{Exp}_{i, s, t}^{A}$ & $\Delta \operatorname{Exp}_{i, s, t}^{B}$ & $\Delta \operatorname{Exp}_{i, s, t}^{C}$ & $\operatorname{Exp}_{t}$ & $\Delta E x p_{i, s, t}^{A}$ & $\Delta \operatorname{Exp}_{i, s, t}^{B}$ & $\Delta \operatorname{Exp}_{i, s, t}^{C}$ \\
\hline 30 & 60 & $30 \%$ & $100 \%$ & $0 \%$ & 140 & $110 \%$ & $367 \%$ & $40 \%$ \\
\hline 20 & 40 & $20 \%$ & $100 \%$ & $0 \%$ & 10 & $-10 \%$ & $-50 \%$ & $-15 \%$ \\
\hline 20 & 40 & $20 \%$ & $100 \%$ & $0 \%$ & 20 & $0 \%$ & $0 \%$ & $-10 \%$ \\
\hline 2 & 4 & $2 \%$ & $100 \%$ & $0 \%$ & 4 & $2 \%$ & $100 \%$ & $0 \%$ \\
\hline 28 & 56 & $28 \%$ & $100 \%$ & $0 \%$ & 26 & $-2 \%$ & $-7 \%$ & $-15 \%$ \\
\hline 100 & 200 & $100 \%$ & $100 \%$ & $0 \%$ & 200 & $100 \%$ & $100 \%$ & $0 \%$ \\
\hline \multicolumn{9}{|c|}{ Decrease: } \\
\hline $\operatorname{Exp}_{t-1}$ & $E x p_{t}$ & $\Delta \operatorname{Exp}_{i, s, t}^{A}$ & $\Delta \operatorname{Exp}_{i, s, t}^{B}$ & $\Delta \operatorname{Exp}_{i, s, t}^{C}$ & $\operatorname{Exp}_{t}$ & $\Delta \operatorname{Exp}_{i, s, t}^{A}$ & $\Delta E x p_{i, s, t}^{B}$ & $\Delta E x p_{i, s, t}^{C}$ \\
\hline 30 & 15 & $-15 \%$ & $-50 \%$ & $0 \%$ & 0 & $-30 \%$ & $-100 \%$ & $-30 \%$ \\
\hline 20 & 10 & $-10 \%$ & $-50 \%$ & $0 \%$ & 5 & $-15 \%$ & $-75 \%$ & $-10 \%$ \\
\hline 20 & 10 & $-10 \%$ & $-50 \%$ & $0 \%$ & 15 & $-5 \%$ & $-25 \%$ & $10 \%$ \\
\hline 2 & 1 & $-1 \%$ & $-50 \%$ & $0 \%$ & 1 & $-1 \%$ & $-100 \%$ & $0 \%$ \\
\hline 28 & 14 & $-14 \%$ & $-50 \%$ & $0 \%$ & 29 & $1 \%$ & $4 \%$ & $30 \%$ \\
\hline 100 & 50 & $-50 \%$ & $-50 \%$ & $0 \%$ & 50 & $-50 \%$ & $-50 \%$ & $0 \%$ \\
\hline
\end{tabular}

This table illustrates how the exposure measures described in Section 4 diverge under different changes to the sovereign portfolio. The top panel demonstrates how the different measures behave when the total size of the sovereign portfolio is increased from 100 to 200, either uniformly (top left) or divergently (top right). The bottom panel displays the variation for a decrease from 100 to 50, either uniformly (bottom left) or divergently (bottom right). $\Delta \operatorname{Exp}_{i, s, t}^{A}$ represents the change to the sovereign exposure relative to the size of the total sovereign debt portfolio at time $t-1 . \Delta E x p_{i, s, t}^{B}$ represents the logarithmic change to the size of the sovereign exposure at time $t$, relative to its size at time $t-1 . \Delta E x p_{i, s, t}^{C}$ represents the difference between the weights of the exposure in the total sovereign debt portfolio at times $t$ and $t-1$. 


\subsection{Risk-Return Trade-Off}

Data to capture the risk-return characteristics of sovereign bonds held by banks are obtained from Refinitiv Datastream, where we collect daily yields-to-maturity of sovereign bonds held by European banks. The EBA data contains only the gross carrying amount of sovereign bonds and do not have information on bank holdings of bonds at the ISIN level, meaning we cannot consistently observe the remaining maturity of each bank's sovereign holdings. Following Buch et al. (2016), we use the 10-year zero-coupon sovereign bond rate as the representative rate for each bond holding. The EU countries for which we cannot obtain 10-year bond yields are dropped from the sample. ${ }^{6}$ We use several risk-return characteristics of these bonds. First, we transform the time series of yields-to-maturity to zero-coupon bond prices at time $t$ :

$$
P_{s, t}=\frac{100}{\left(1+Y T M_{s, t}^{10 y}\right)^{10}}
$$

and at time $t-1$, where we correct for the fact that the bond is one day further from maturity. ${ }^{7}$ As such, the price of the bonds at $t$ and $t-1$ are calculated as if they have the same maturity at time $t$.

We then calculate the daily holding period return (HPR) for each bond as:

$$
r_{s, t}^{H P R}=\ln \left(\frac{P_{s, t}}{P_{s, t-1}}\right) .
$$

Using these HPRs, we obtain, for each sovereign bond and each semi-annual period, the realized return as the average daily HPR, and the realized volatility as the standard deviation of the daily HPRs. The Sharpe ratio, being our main variable of interest, is then obtained by taking the ratio of the realized return and the realized volatility and annualizing it using 252 trading days per year. ${ }^{8}$ Moreover, to capture the risk-return trade-off in other ways, we also use the yield-to-maturity (YTM) on 10-year zero coupon bonds as a proxy for the expected return, and add the 5-year CDS spreads on sovereign bonds, in order to capture the (tail) risk of a default on sovereign debt.

\subsection{Bank-Specific Variables}

To control for bank-specific characteristics in banks' purchasing behavior, we add data on bank balance sheets and income statements from S\&P Global Market Intelligence. To match the frequency of the EBA data, bank balance sheet and income statement data are extracted at a semiannual frequency. We use the most recently available data point when a variable is not available at a certain point in time. With this data, we calculate several commonly used bank performance and bank risk variables, as well as variables capturing business model characteristics. All bank-level control variables are lagged one period and winsorized at the 1st and 99th percentile.

To control for the business model of banks, we include various bank-level variables which might determine purchasing behavior. We include the log of total assets as a measure of bank size. Large banks may be diversified geographically, and for that reason, may be less prone to a home bias in their investment portfolio, leading to a more diversified portfolio. Capital adequacy is proxied by the unweighted equity-to-assets ratio. ${ }^{9}$ The expected influence of capital on sovereign bond holdings is mixed. A bank with a high capital ratio may want to protect its franchise value by lowering the riskiness of its assets; hence, low-risk sovereign bonds may be attractive. On the other hand, well-capitalized banks have the ability to take risk, and this may incentivize them to invest in riskier assets and avoid sovereign bonds. It is important to note that sovereign bonds carry a zero-risk weight in the calculation of the banks' capital requirements since all countries have taken advantage of the zero-risk exception for sovereign bonds. Bank capital may also be related to the risk-taking behavior of banks, as banks engaging in excessive risk taking are typically 
characterized by low capital ratios (see, e.g., Altunbas et al. 2012; Berger and Bouwman 2013; Heider et al. 2019; Jiménez et al. 2014; Lamers et al. 2019; Vazquez and Federico 2015).

The ratio of non-performing loans (NPL) to total loans is included to account for the risk profile of the banks' loan portfolios. The expectation is that banks with a more risky loan portfolio have the incentive to lower their risk profile by, e.g., investing more in low-risk sovereign securities. However, risky banks may elect to gamble and increase their risk by divesting low-risk sovereign exposures and/or increasing exposures to highrisk sovereigns.

The loan-to-deposit ratio (LDR) is considered to be a measure of both liquidity risk and interest rate risk. When a bank has a high LDR, part of the funding for its loan portfolio comes from non-deposit, and hence, potentially more volatile sources. This may incentivize the bank to hold sovereign bonds which are eligible for refinancing operations both with the central bank and via financial markets (e.g., repos).

The proportion of cash and reserves at the central bank in total assets is an indicator of the core liquidity position of a bank. Since sovereign bonds are the closest substitute for very liquid assets, the expectation is that this variable will exhibit a negative sign in explaining bank sovereign bond holdings.

\subsection{Summary Statistics}

Merging the different data sources yields a multidimensional panel varying over bank, sovereign, and time dimensions. The dataset consists of 17,402 observations covering 75 banks with exposures to 22 EU countries at 13 points in time, for which summary statistics can be found in the different panels of Table 2.

Table 2. Descriptive statistics.

\begin{tabular}{|c|c|c|c|c|c|}
\hline & $N$ & Mean & $S D$ & Min & $\operatorname{Max}$ \\
\hline \multicolumn{6}{|l|}{ Panel A: Exposure measures } \\
\hline Within-sovereign portfolio $\left(\Delta \operatorname{Exp}_{i, s, t}^{A}\right.$, in $\left.\%\right)$ & 15,048 & 0.08 & 1.96 & -8.27 & 11.48 \\
\hline Within-exposure $\left(\Delta \operatorname{Exp}_{i, s, t}^{B}\right.$, in \%) & 7855 & 0.88 & 96.31 & -424.04 & 425.63 \\
\hline Change in weight $\left(\Delta \operatorname{Exp}_{i, t, t}^{C}\right.$, in $\left.\left.\%\right)\right)$ & 15,048 & 0.01 & 1.33 & -6.35 & 6.43 \\
\hline Exposure weight $\left(\operatorname{Exp}_{i, s, t}\right.$, in $\left.\%\right)$ & 17,138 & 4.55 & 15.32 & 0.00 & 100.00 \\
\hline \multicolumn{6}{|l|}{ Panel B: Risk-return measures } \\
\hline Sharpe ratio & 17,380 & 0.76 & 1.52 & -2.48 & 4.37 \\
\hline Real. return (in \%) & 17,380 & 6.23 & 16.98 & -84.05 & 63.13 \\
\hline Real. volatility (in \%) & 17,380 & 10.55 & 11.31 & 2.86 & 80.21 \\
\hline YTM (in \%) & 17,380 & 2.82 & 2.42 & 0.22 & 12.57 \\
\hline $\mathrm{CDS}_{\text {Sovereign }}($ in $\%)$ & 17,380 & 7.79 & 46.35 & 0.10 & 370.30 \\
\hline \multicolumn{6}{|l|}{ Panel C: Bank controls } \\
\hline $\operatorname{Ln}(\mathrm{TA})_{t-1}$ & 17,380 & 19.01 & 1.46 & 15.29 & 21.50 \\
\hline Equity/Total Assets $t_{-1}$ (in \%) & 17,380 & 6.40 & 2.64 & 1.28 & 14.60 \\
\hline NPL/Loans $t_{t-1}($ in $\%)$ & 16,896 & 11.74 & 12.86 & 0.53 & 60.60 \\
\hline Loans/Deposits $_{t-1}($ in \%) & 17,358 & 118.81 & 37.00 & 34.02 & 233.71 \\
\hline Cash/Total Assets $t_{t-1}$ (in \%) & 17,314 & 10.89 & 6.13 & 2.02 & 30.84 \\
\hline Pre-tax $\mathrm{ROA}_{t-1}($ in $\%)$ & 17,380 & 0.26 & 1.06 & -4.32 & 2.51 \\
\hline
\end{tabular}

Panel A shows descriptive statistics for the different exposure measures. Panel B shows descriptive statistics for the risk-return measures. Panel $C$ shows descriptive statistics for the bank variables.

Panel A displays the different net changes in portfolio holdings of banks. The mean of the within-sovereign portfolio change of 0.08 percent shows that, on average, the sovereign exposure portfolios of banks have grown over time. This slow average build-up comes with spells of large increases and decreases of the exposure to a specific country where banks (re)invest, at most, around 10 percent of their sovereign bond portfolio. Similar large increases and decreases are observed for both other definitions of the change in exposures. 
Panel B shows the Sharpe ratios and other variables capturing the risk-return tradeoff. The annualized Sharpe ratio is, on average, quite high (0.74), which is likely caused by price increases over our sample period due to accommodative monetary policy. The average realized return over all 22 countries is 6.4 percent, accentuating the persistent drop in yields since the sovereign debt crisis. Furthermore we find large differences in the yield-to-maturity across countries, with a low for Germany at 0.2 percent and a high for Greece at 12.6 percent. This gives banks ample opportunity to invest in high-yielding sovereigns at a higher risk, or in safe sovereigns with a lower associated yield.

As the Sharpe ratio is our main variable of interest, we plot its evolution over time for the 22 EU countries in our sample in Figure 1. We observe some stylized facts across time and across regions. First, there is a large variation in the Sharpe ratio, ranging from -2.7 to 4.4. Second, for the Core and Nordic/Ireland/UK regions, the evolution over time is quite homogeneous across countries, which is why we use time-fixed effects in our regressions. In the Peripheral and CEEC regions, the variation is much more heterogeneous across countries. Third, the mean over time of the Sharpe ratios is similar for all countries, with 0.39 (Czech Republic) as the lowest value and 1.52 (Ireland) as the highest mean Sharpe ratio.

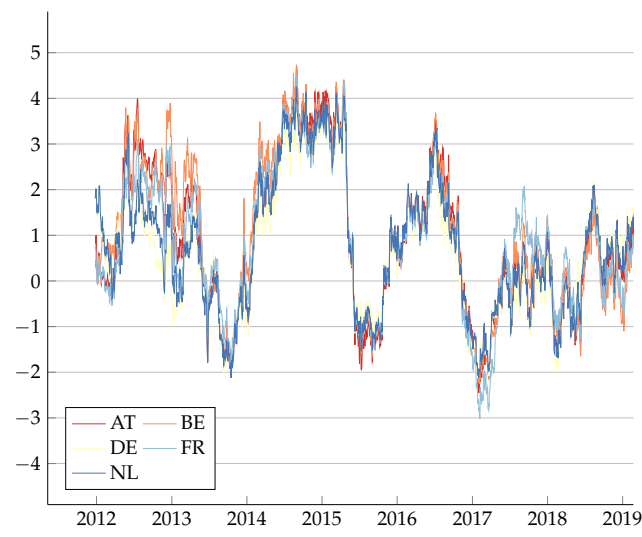

(a) Core

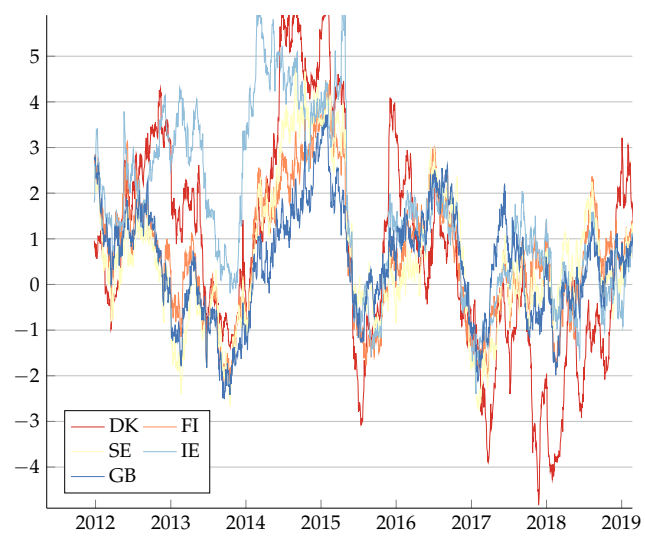

(c) Nordic/IE/UK

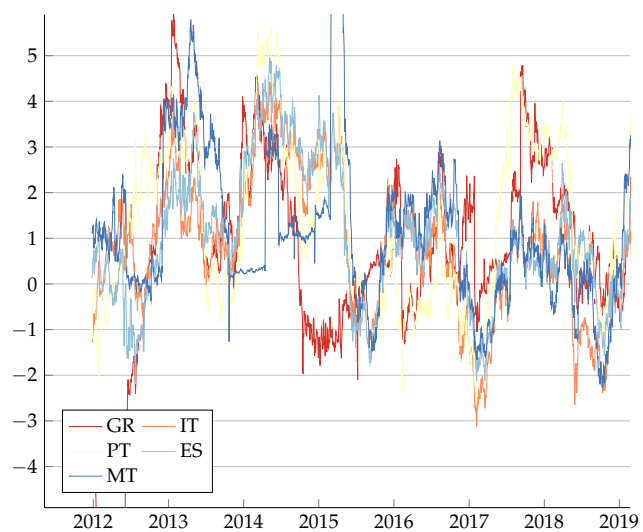

(b) Periphery

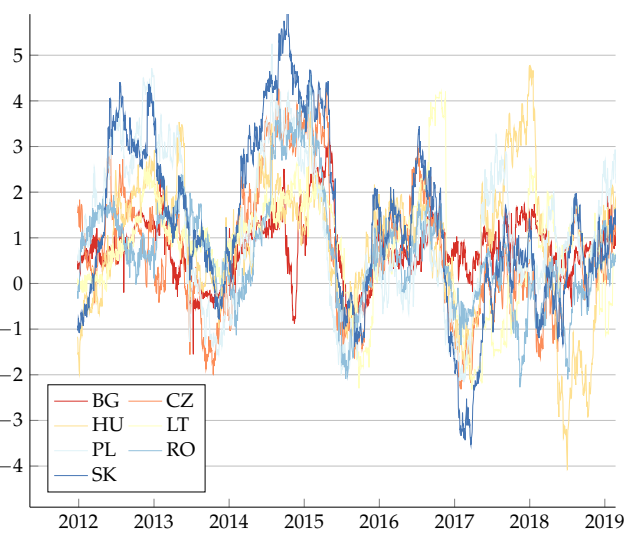

(d) CEEC

Figure 1. This figure plots the evolution of annualized Sharpe ratios over time for different regions within the EU.

Panel $\mathrm{C}$ in Table 2 provides summary statistics for the bank-level variables. The sample includes the largest banks in the EU, as shown by the size of total assets. Equityto-assets ranges from 14.6 percent for the most-capitalized banks to 1.28 percent for the least-capitalized banks. The differences in risk profiles of the banks is further emphasized by the wide range of non-performing loans, which runs from 0.53 percent to 60.60 percent for the riskiest bank. On average, the banks in our sample fund their loan portfolio with 
deposits and have a cash buffer of 10.89 percent. Pre-tax return on assets averages 0.26 percent over time and across banks.

\section{Results}

\subsection{Bank Sovereign Bond Investment Behavior}

To test the hypothesis that banks take into account the risk and return dimensions of sovereign bonds when managing their securities portfolio, we estimate Equation (1) for the two subperiods. The results using the within-sovereign portfolio change, $\Delta \operatorname{Exp}_{i, s, t}^{A}$, are shown in Table 3. The Table is structured in three parts to cover the different riskreturn measures. Columns (1)-(3) show the results for the Sharpe ratio, columns (4)-(6) the results when decomposing the Sharpe ratio in its return and volatility components, and columns (7)-(9) the results when using the yield-to-maturity and the sovereign CDS as risk-return measures. Furthermore, each set of columns is saturated with different fixed effects. In columns (1), (4), and (7), we use bank-, country-, and time-fixed effects in order to control for possible unobserved heterogeneity in each of the three dimensions separately. In columns (2), (5), and (8), we add bank-time-fixed effects to absorb all banklevel heterogeneity in determining investments or divestments, only using the betweensovereign variation in the risk-return dimension. Finally, in columns (3), (6), and (9), we add bank-country-fixed effects, allowing us to exploit only the time variation within a bank-country pair. ${ }^{10}$

The results for the sovereign debt crisis period 2011-2014 can be found in Panel A, while Panel B contains the findings for 2015-2018, characterized by the ECB's unconventional monetary policy. It is immediately clear that the two periods are characterized by different bank sovereign bond investing behaviors. In the 2011-2014 period, all variables capturing the risk-return trade-off are not significant. Since this is the case both for the Sharpe ratio and its components, we conclude that in the period of the sovereign debt crisis, prudent risk-return considerations were absent in the banks' management of their sovereign portfolios. Worse, since the sovereign CDS spreads carry a significant positive sign in most specifications, and this is also the case for the home bias variable, the conclusion is that banks were mainly buying domestic sovereign bonds in the riskier countries. This is consistent with a risk-taking hypothesis, and our results confirm the previous findings of excessive risk-taking - especially by banks in peripheral Euro Area countries (see, e.g., Acharya et al. 2014; Altavilla et al. 2017).

The picture changes in the period 2015-2018. Column (1) shows that the decision to invest in a sovereign bond is now significantly positively associated with the Sharpe ratio, indicating that banks consider the risk-return trade-off in their sovereign bond investment decisions and, hence, operate as rational investors. In columns (2) and (3), we introduce bank-time-fixed effects and bank-country-fixed effects. With the former, we analyze whether the same bank at the same point in time has higher net purchases of bonds with a better risk-return trade-off, and with the latter, we control for the fact that some sovereign bonds might have a better risk-return trade-off throughout the sample period, or that certain banks have preferences to purchase bonds of a certain sovereign. The results are robust, including both types of fixed effects. In terms of economic significance, a 1-standard-deviation increase in the Sharpe ratio of a sovereign bond is associated with an increase in the bond holding by 0.11 percent of the total sovereign portfolio. This corresponds to 137 percent of the average change in the dependent variable.

Columns (4)-(6) consider the components of the Sharpe ratio separately, and we find that in the period 2015-2018, bank sovereign bond investments load positively on the bond return, implying that banks consider the return of the bonds in which they invest. The coefficient on the volatility is negative but insignificant, implying that banks avoid high-risk bonds. Columns (7)-(9) show the results when using the YTM to capture the risk-return trade-off. The results are comparable to columns (4)-(6), as the YTM has a significantly positive coefficient. This finding strengthens the view that banks acted as rational investors in 2015-2018, as they chose higher yielding bonds even when controlling 
for the risk of the sovereign as proxied by the CDS spread. A 1-standard-deviation increase in the YTM of a sovereign is associated with an increase in the bond holding between 0.23 and 0.27 percent of the total sovereign portfolio, corresponding to between 287 and 337 percent of the average change in the dependent variable.

Table 3. Model for the intensive margin in both subperiods.

\begin{tabular}{|c|c|c|c|c|c|c|c|c|c|}
\hline $\begin{array}{c}\text { Column } \\
\text { Dependent Variable }\end{array}$ & $\begin{array}{c}(1) \\
\Delta \operatorname{Exp}_{i, s, t}^{A}\end{array}$ & $\begin{array}{c}(2) \\
\Delta \operatorname{Exp}_{i, s, t}^{A}\end{array}$ & $\begin{array}{c}(3) \\
\Delta \operatorname{Exp}_{i, s, t}^{A}\end{array}$ & $\begin{array}{c}(4) \\
\Delta \operatorname{Exp}_{i, s, t}^{A}\end{array}$ & $\begin{array}{c}(5) \\
\Delta \operatorname{Exp}_{i, s, t}^{A}\end{array}$ & $\begin{array}{c}\text { (6) } \\
\Delta \operatorname{Exp}_{i, s, t}^{A}\end{array}$ & $\begin{array}{c}(7) \\
\Delta \operatorname{Exp}_{i, s, t}^{A}\end{array}$ & $\begin{array}{c}(8) \\
\Delta \operatorname{Exp}_{i, s, t}^{A}\end{array}$ & $\begin{array}{c}\text { (9) } \\
\Delta \operatorname{Exp}_{i, s, t}^{A}\end{array}$ \\
\hline \multicolumn{10}{|c|}{ Panel A: July 2011-December 2014} \\
\hline Sharpe ratio & $\begin{array}{c}0.011 \\
(0.444)\end{array}$ & $\begin{array}{c}0.013 \\
(0.528)\end{array}$ & $\begin{array}{c}0.026 \\
(0.928)\end{array}$ & & & & & & \\
\hline Real. return & & & & $\begin{array}{c}0.005 \\
(1.536)\end{array}$ & $\begin{array}{c}0.005 \\
(1.516)\end{array}$ & $\begin{array}{l}0.005^{*} \\
(1.688)\end{array}$ & & & \\
\hline Real. volatility & & & & $\begin{array}{l}-0.001 \\
(-0.324)\end{array}$ & $\begin{array}{c}-0.001 \\
(-0.315)\end{array}$ & $\begin{array}{c}-0.001 \\
(-0.389)\end{array}$ & & & \\
\hline YTM & & & & & & & $\begin{array}{c}0.017 \\
(0.471)\end{array}$ & $\begin{array}{c}0.021 \\
(0.603)\end{array}$ & $\begin{array}{c}0.045 \\
(1.139)\end{array}$ \\
\hline $\mathrm{CDS}_{\text {Sovereign }}$ & $\begin{array}{l}0.007^{*} \\
(1.750)\end{array}$ & $\begin{array}{l}0.007^{*} \\
(1.755)\end{array}$ & $\begin{array}{c}0.010^{* * *} \\
(3.159)\end{array}$ & $\begin{array}{c}-0.001 \\
(-0.122)\end{array}$ & $\begin{array}{c}-0.000 \\
(-0.067)\end{array}$ & $\begin{array}{c}0.003 \\
(0.506)\end{array}$ & $\begin{array}{c}0.007^{* *} \\
(2.024)\end{array}$ & $\begin{array}{c}0.007^{* *} \\
(2.054)\end{array}$ & $\begin{array}{c}0.011^{* * *} \\
(4.107)\end{array}$ \\
\hline Home & $\begin{array}{c}1.948^{* * *} \\
(4.299)\end{array}$ & $\begin{array}{c}1.915^{* * *} \\
(4.398)\end{array}$ & & $\begin{array}{l}1.947^{* * *} \\
(4.300)\end{array}$ & $\begin{array}{l}1.915^{* * *} \\
(4.400)\end{array}$ & & $\begin{array}{l}1.949 * * * \\
(4.302)\end{array}$ & $\begin{array}{l}1.917^{* * *} \\
(4.402)\end{array}$ & \\
\hline Bank controls & Yes & - & Yes & Yes & - & Yes & Yes & - & Yes \\
\hline Country-fixed effects & Yes & Yes & - & Yes & Yes & - & Yes & Yes & - \\
\hline Bank-fixed effects & Yes & - & - & Yes & - & - & Yes & - & - \\
\hline Time-fixed effects & Yes & - & Yes & Yes & - & Yes & Yes & - & Yes \\
\hline Bank-Time-fixed effects & - & Yes & - & - & Yes & - & - & Yes & - \\
\hline Bank-Country-fixed effects & - & - & Yes & - & - & Yes & - & - & Yes \\
\hline $\bar{R}^{2}$ & 0.055 & 0.071 & 0.046 & 0.055 & 0.071 & 0.046 & 0.055 & 0.071 & 0.046 \\
\hline $\bar{R}_{\text {within }}^{2}$ & 0.035 & 0.034 & 0.004 & 0.035 & 0.034 & 0.004 & 0.035 & 0.034 & 0.004 \\
\hline No. of obs & 6182 & 6358 & 5808 & 6182 & 6358 & 5808 & 6182 & 6358 & 5808 \\
\hline \multicolumn{10}{|c|}{ Panel B: January 2015-June 2018} \\
\hline Sharpe ratio & $\begin{array}{c}0.081^{* * *} \\
(3.781)\end{array}$ & $\begin{array}{c}0.085^{* * *} \\
(4.095)\end{array}$ & $\begin{array}{c}0.082 * * * \\
(3.778)\end{array}$ & & & & & & \\
\hline Real. return & & & & $\begin{array}{c}0.007^{* * *} \\
(3.487)\end{array}$ & $\begin{array}{c}0.007^{* * *} \\
(3.594)\end{array}$ & $\begin{array}{c}0.007^{* * *} \\
(3.476)\end{array}$ & & & \\
\hline Real. volatility & & & & $\begin{array}{c}-0.006 \\
(-1.128)\end{array}$ & $\begin{array}{c}-0.006 \\
(-1.132)\end{array}$ & $\begin{array}{c}-0.007 \\
(-1.193)\end{array}$ & & & \\
\hline YTM & & & & & & & $\begin{array}{c}0.133^{* *} \\
(1.988)\end{array}$ & $\begin{array}{c}0.133^{* *} \\
(2.024)\end{array}$ & $\begin{array}{c}0.157^{* *} \\
(2.359)\end{array}$ \\
\hline $\mathrm{CDS}_{\text {Sovereign }}$ & $\begin{array}{c}0.018 \\
(1.494)\end{array}$ & $\begin{array}{c}0.019 \\
(1.568)\end{array}$ & $\begin{array}{c}0.007 \\
(0.711)\end{array}$ & $\begin{array}{l}0.067^{*} \\
(1.934)\end{array}$ & $\begin{array}{c}0.067 * * \\
(1.993)\end{array}$ & $\begin{array}{c}0.055 \\
(1.619)\end{array}$ & $\begin{array}{c}-0.034 \\
(-1.600)\end{array}$ & $\begin{array}{c}-0.034 \\
(-1.584)\end{array}$ & $\begin{array}{c}-0.055^{* * *} \\
(-2.875)\end{array}$ \\
\hline Home & $\begin{array}{l}-0.400 \\
(-1.199)\end{array}$ & $\begin{array}{l}-0.351 \\
(-1.090)\end{array}$ & & $\begin{array}{l}-0.400 \\
(-1.197)\end{array}$ & $\begin{array}{c}-0.351 \\
(-1.088)\end{array}$ & & $\begin{array}{l}-0.402 \\
(-1.204)\end{array}$ & $\begin{array}{l}-0.354 \\
(-1.096)\end{array}$ & \\
\hline Bank controls & Yes & - & Yes & Yes & - & Yes & Yes & - & Yes \\
\hline Country-fixed effects & Yes & Yes & - & Yes & Yes & - & Yes & Yes & - \\
\hline Bank-fixed effects & Yes & - & - & Yes & - & - & Yes & - & - \\
\hline Time-fixed effects & Yes & - & Yes & Yes & - & Yes & Yes & - & Yes \\
\hline Bank-Time-fixed effects & - & Yes & - & - & Yes & - & - & Yes & - \\
\hline Bank-Country-fixed effects & - & - & Yes & - & - & Yes & - & - & Yes \\
\hline $\bar{R}^{2}$ & 0.018 & 0.037 & 0.020 & 0.018 & 0.036 & 0.019 & 0.017 & 0.036 & 0.019 \\
\hline $\bar{R}_{\text {within }}^{2}$ & 0.004 & 0.003 & 0.002 & 0.003 & 0.002 & 0.002 & 0.003 & 0.002 & 0.001 \\
\hline No. of obs & 8360 & 8690 & 8008 & 8360 & 8690 & 8008 & 8360 & 8690 & 8008 \\
\hline
\end{tabular}


The positive coefficient on bond returns is not inconsistent with banks searching for yields, and the same interpretation holds for the positive coefficient of YTM in columns (7)-(9). But the negative, albeit insignificant, coefficient on bond yield volatility is not compatible with the hypothesis of excessive risk-taking by banks in the second period. A sound risk-return trade-off does not prevent the banks from investing in bonds with higher yields, as long as this is not accompanied by tilting the portfolio towards bonds with higher risk. Moreover, the positive coefficient of sovereign CDS spreads in the period 2011-2014, indicating risk-seeking behavior, turns insignificant or even negative in some specifications in 2015-2018, again indicating that banks refrained from further investing in riskier sovereigns. Finally, the home bias variable becomes insignificant and negative, suggesting that, if anything, banks were diversifying their sovereign bond holdings away from the domestic sovereign. Hence, in the period 2015-2018, in which decreasing bond yields may have provided incentives to increase risk taking, European banks applied a more prudent risk-return behavior, at least in their sovereign bond portfolios, and this represents a departure from their excessive risk behavior in the first period. For bank supervisors and regulators, this implies that the sovereign bond portfolios of the banks have evolved towards a more sustainable risk profile, potentially due to regulatory pressure.

\subsection{Different Behavior in GIPS Region}

Another important dimension of the bank-sovereign doom loop is the geographical scope. The sovereign debt crisis had a heterogeneous impact on different regions in Europe, and this may yield a different impact for the risk-return trade-off behavior in the banks' sovereign portfolios. We split the sample between GIPS countries (Greece, Italy, Portugal, and Spain), which were hit hardest, and other countries, both for the banks and for the sovereign exposures they hold. This allows us to investigate whether or not (non-)GIPS banks take into account the risk-return trade-off differently for GIPS or nonGIPS sovereigns. The analysis is performed in one step by interacting our variable of interest with regional dummies for both the bank and the sovereign exposure, as indicated in Equation (8):

$$
\begin{aligned}
\Delta \operatorname{Exp}_{i, s, t}^{A}= & \beta_{1} \text { Risk-return trade-off }_{s, t} \\
& +\beta_{2} \text { Sovereign }_{G I P S} \times \text { Risk-return trade-off }_{s, t} \\
& +\beta_{3} \text { Bank }_{\text {GIPS }} \times \text { Risk-return trade-off }_{s, t} \\
& +\beta_{4} \text { Bank }_{\text {GIPS }} \times \text { Sovereign }_{\text {GIPS }} \times \text { Risk-return trade-off }_{s, t} \\
& +\beta_{5} \text { Bank }_{\text {GIPS }} \times \text { Sovereign }_{\text {GIPS }}+\beta_{6} X_{i, t}+\beta_{7} \varphi_{s}+\beta_{8} \mu_{i}+\beta_{9} \tau_{t}+\epsilon_{i, s, t}
\end{aligned}
$$

For banks located in the GIPS region, the domestic sovereign is included in the regional dummy for the sovereign exposure. To avoid that the results for these banks would be driven by the exposure towards the home country, we perform the analysis in Equation (8) excluding all exposures to the home country.

To facilitate the interpretation of the coefficients for the different interactions, we summarize the findings in Table 4 which presents the combined (marginal) effects for each region derived from Equation (8). ${ }^{11}$ Table 4 yields a number of important insights. First, in the period 2011-2014, non-GIPS banks did not appear to apply a risk-return trade-off for both GIPS and non-GIPS bonds. However, similar to Section 5.1, in the second subperiod, the results completely change. Non-GIPS banks' investment behavior now loads significantly and positively on the Sharpe ratio. When looking at the component of the Sharpe ratio, this result seems mainly driven by the return component of the Sharpe ratio. Moreover, for investments in GIPS countries, non-GIPS banks also actively avoid high-volatility sovereign bonds between 2015-2018. Taken together, these results are not consistent with a search for yields or a flight to safety, but rather with a shift to a sound risk-return trade-off in the sovereign portfolio investment decisions of non-GIPS banks. With this type of behavior, they comply with the recommendations of their supervisors. 
For GIPS banks, the picture is less clear. In the period 2011-2014, the investments in non-home GIPS sovereigns by GIPS banks load positively on the Sharpe ratio, indicating that these investments were driven by risk-return considerations, although the coefficient is only significant at the $10 \%$ level. However, when considering the components of the Sharpe ratio, there is no clear indication whether this is driven by banks seeking high-return bonds or actively avoiding high-volatility bonds. In the period 2015-2018, the marginal effects have the same magnitude and sign as for the non-GIPS banks, but most of these results are not statistically significant. In any case, our results indicate that GIPS banks, which were already accused of being excessively exposed to their home sovereigns, did not apply a sound risk-return trade-off in the period following the sovereign debt crisis.

Table 4. Total impact of split by regional origination.

\begin{tabular}{|c|c|c|c|c|c|c|c|}
\hline \multirow{2}{*}{ Bank } & \multirow{2}{*}{ Sovereign } & \multicolumn{2}{|c|}{ Sharpe Ratio } & \multicolumn{2}{|c|}{ Real. Return } & \multicolumn{2}{|c|}{ Real. Volatility } \\
\hline & & 2011-2014 & 2015-2018 & 2011-2014 & 2015-2018 & 2011-2014 & 2015-2018 \\
\hline \multirow{4}{*}{ Non-GIPS } & Non-GIPS & 0.014 & $0.031 *$ & -0.001 & 0.004 & 0.002 & 0.000 \\
\hline & & $(0.60)$ & (1.89) & $(-0.51)$ & (1.61) & $(0.93)$ & $(0.01)$ \\
\hline & GIPS & 0.001 & $0.105^{* * *}$ & 0.001 & $0.004 * * *$ & -0.004 & $-0.007^{* * *}$ \\
\hline & & $(0.03)$ & $(3.71)$ & $(0.27)$ & $(3.85)$ & $(-1.23)$ & $(-3.54)$ \\
\hline \multirow{4}{*}{ GIPS } & Non-GIPS & $-0.033 *$ & 0.016 & $-0.006^{*}$ & 0.000 & $0.008^{* * *}$ & -0.009 \\
\hline & & $(-1.66)$ & $(0.38)$ & $(-1.83)$ & $(0.03)$ & $(3.20)$ & $(-1.22)$ \\
\hline & GIPS & 0.158 * & 0.088 & 0.004 & 0.000 & -0.009 & -0.001 \\
\hline & & (1.94) & (1.02) & (1.09) & $(0.22)$ & $(-1.56)$ & $(-0.24)$ \\
\hline
\end{tabular}

This table shows the total impact of the risk-return measures for the different combinations of regional origination. The GIPS region encompasses the countries Greece, Italy, Portugal, and Spain. Our sample consists of 29 banks from the GIPS region and 46 banks from the non-GIPS region. All exposures to the domestic sovereign are excluded from the analysis. The coefficients and t-statistics are derived from the model with bank-, sovereign-, and time-fixed effects. ${ }^{*}$ significant at 10 percent; ${ }^{* * *}$ significant at 1 percent. t-statistics between brackets.

\subsection{Impact of Bank Business Model Characteristics}

Finally, we interact the Sharpe ratio with different balance sheet characteristics to analyze whether we can observe heterogeneous behavior across banks. For instance, previous research has shown that lowly capitalized banks have engaged in search-for-yield behavior (Acharya and Steffen 2015). To do so, we interact the Sharpe ratio with our bank-level balance sheet characteristics in Table 5. Overall, very few interactions with the Sharpe ratio are statistically significant. In the period 2011-2014, none of the interactions are statistically significant, while in the period 2015-2018 only the interaction with the non-performing loans ratio is significant, indicating that banks with higher non-performing loan ratios exhibit, to a lesser extent, the risk-return trade-off. Similar to Acharya and Steffen (2015), this might be caused by banks with a more risky loan portfolio engaging in a search for yields. 
Table 5. Model by business model.

\begin{tabular}{|c|c|c|}
\hline $\begin{array}{c}\text { Column } \\
\text { Dependent Variable }\end{array}$ & \multicolumn{2}{|c|}{$\Delta \operatorname{Exp}_{i, s, t}^{A}$} \\
\hline Years & 2011-2014 & 2015-2018 \\
\hline $\begin{array}{c}\text { Sharpe ratio } \\
\operatorname{Ln}(\mathrm{TA})_{t-1}{ }^{*} \text { Sharpe ratio }\end{array}$ & $\begin{array}{c}-0.191 \\
(-0.574) \\
0.004 \\
(0.274)\end{array}$ & $\begin{array}{c}0.118 \\
(0.422) \\
-0.004 \\
(-0.304)\end{array}$ \\
\hline $\begin{array}{c}\text { Equity/Total Assets } \text { Ast }_{t} * \text { Sharpe } \\
\text { ratio }\end{array}$ & 0.012 & 0.011 \\
\hline NPL/Loans $t_{t-1}{ }^{*}$ Sharpe ratio & $\begin{array}{c}(1.460) \\
-0.001 \\
(-0.470)\end{array}$ & $\begin{array}{c}(1.454) \\
-0.003 * \\
(-1.689)\end{array}$ \\
\hline $\begin{array}{c}\text { Loans/Deposits } \\
\text { ratio }\end{array}$ & 0.000 & -0.000 \\
\hline & $(0.733)$ & $(-0.265)$ \\
\hline $\begin{array}{c}\text { Cash/Total Assets } \text { As-1 }^{*} \text { Sharpe } \\
\text { ratio }\end{array}$ & 0.002 & 0.001 \\
\hline Pre-tax $\mathrm{ROA}_{t-1}{ }^{*}$ Sharpe ratio & $\begin{array}{c}(0.456) \\
0.014 \\
(0.715)\end{array}$ & $\begin{array}{c}(0.357) \\
-0.030 \\
(-1.199)\end{array}$ \\
\hline $\operatorname{Ln}(\mathrm{TA})_{t-1}$ & $\begin{array}{l}-0.296 \\
(-0.780)\end{array}$ & $\begin{array}{l}-1.004^{* *} \\
(-2.501)\end{array}$ \\
\hline Equity/Total Assets ${ }_{t-1}$ & $\begin{array}{c}0.051 \\
(1.429)\end{array}$ & $\begin{array}{l}-0.052 \\
(-0.876)\end{array}$ \\
\hline NPL/Loans ${ }_{t-1}$ & $\begin{array}{l}-0.016 \\
(-1.468)\end{array}$ & $\begin{array}{l}-0.004 \\
(-0.609)\end{array}$ \\
\hline Loans/Deposits $_{t-1}$ & $\begin{array}{c}0.004 \\
(1.176)\end{array}$ & $\begin{array}{c}0.000 \\
(0.204)\end{array}$ \\
\hline Cash/Total Assets ${ }_{t-1}$ & $\begin{array}{l}0.047^{* *} \\
(2.264)\end{array}$ & $\begin{array}{c}0.011 \\
(0.976)\end{array}$ \\
\hline Pre-tax $\mathrm{ROA}_{t-1}$ & $\begin{array}{c}-0.008 \\
(-0.168)\end{array}$ & $\begin{array}{l}0.075^{*} \\
(1.743)\end{array}$ \\
\hline $\mathrm{CDS}_{\text {Sovereign }}$ & $\begin{array}{l}0.007 * \\
(1.744)\end{array}$ & $\begin{array}{c}0.018 \\
(1.491)\end{array}$ \\
\hline Home & $\begin{array}{l}1.953^{* * *} \\
(4.309)\end{array}$ & $\begin{array}{l}-0.396 \\
(-1.187)\end{array}$ \\
\hline Country-fixed effects & Yes & Yes \\
\hline Bank-fixed effects & Yes & Yes \\
\hline Time-fixed effects & Yes & Yes \\
\hline $\bar{R}^{2}$ & 0.055 & 0.018 \\
\hline $\bar{R}_{\text {zwithin }}^{2}$ & 0.035 & 0.003 \\
\hline No. of obs & 6182 & 8360 \\
\hline
\end{tabular}

This table shows the regression results for the model where the risk-return measures are interacted with the bank balance sheet variables. ${ }^{*}$ significant at 10 percent; ${ }^{* *}$ significant at 5 percent; ${ }^{* * *}$ significant at 1 percent. t-statistics between brackets.

\section{Robustness}

In this section, we test whether or not our results are robust to using different measures to capture the change in sovereign exposures, to accounting rules that may influence change in sovereign exposures, and to periods in which moral suasion might materialize.

\subsection{Different Measures of Change in Sovereign Exposures}

To test the impact of the calculation of the change in the banks' sovereign exposures, we use three alternatives for the within-sovereign portfolio change. As explained in Section 4, each of these alternative measures captures different aspects of the asset allocation of banks. With the extensive margin, we focus on the decision of banks whether or not to increase exposure towards a certain country. The within-exposure allocation attaches a higher weight to absolute changes in small exposures over changes in large exposures. Finally, the change in weight deviates from these measures, in that it will assign a change in an exposure conditional on changes in other exposures, so even if the level of the exposure did not change, the weight might still change.

Table 6 displays the results for the alternative exposure measures with the Sharpe ratio as risk-return trade-off. When using the extensive margin $\Delta \operatorname{Exp}_{i, s, t}^{E x t}$, in columns (1) and (2), we observe that the coefficient on the Sharpe ratio is positive and significant in both periods. 
This suggests that, in the period 2011-2014, banks made decisions consistent with a sound risk-return trade-off when deciding whether or not to invest or divest in sovereign bonds. As the extensive margin captures a different dimension of the decision-making process, namely, whether to invest or not, this is not necessarily inconsistent with the results in Table 3, where the dependent variable captures how much to invest in a sovereign. In the period 2015-2018, we find that, similar to Table 3, the effect of the Sharpe ratio increases in magnitude and significance.

Table 6. Robustness: different exposure measures.

\begin{tabular}{|c|c|c|c|c|c|c|}
\hline \multirow{3}{*}{$\begin{array}{c}\text { Column } \\
\text { Dependent Variable } \\
\text { Years }\end{array}$} & (1) & (2) & (3) & (4) & (5) & (6) \\
\hline & \multicolumn{2}{|c|}{$\Delta \operatorname{Exp}_{i, s, t}^{E x t}$} & \multicolumn{2}{|c|}{$\Delta \operatorname{Exp}_{i, s, t}^{B}$} & \multicolumn{2}{|c|}{$\Delta \operatorname{Exp}_{i, s, t}^{C}$} \\
\hline & $2011-2014$ & $2015-2018$ & $2011-2014$ & 2015-2018 & 2011-2014 & 2015-2018 \\
\hline \multirow[t]{2}{*}{ Sharpe ratio } & $0.019 * *$ & $0.029 * * *$ & 1.499 & 0.375 & 0.020 & $0.024 *$ \\
\hline & $(2.008)$ & $(3.054)$ & $(0.706)$ & $(0.210)$ & $(1.267)$ & $(1.751)$ \\
\hline \multirow[t]{2}{*}{$\mathrm{CDS}_{\text {Sovereign }}$} & $0.006^{* * *}$ & $-0.018^{* * *}$ & $2.022^{* * *}$ & $-8.159 * * *$ & $0.009^{* * *}$ & 0.001 \\
\hline & $(5.294)$ & $(-3.042)$ & $(5.315)$ & $(-3.807)$ & $(3.039)$ & $(0.145)$ \\
\hline \multirow[t]{2}{*}{ Home } & 0.098 & $-0.131^{* *}$ & -5.477 & -2.248 & -0.157 & -0.012 \\
\hline & $(1.561)$ & $(-2.532)$ & $(-1.445)$ & $(-0.833)$ & $(-0.677)$ & $(-0.066)$ \\
\hline Country-fixed effects & Yes & Yes & Yes & Yes & Yes & Yes \\
\hline Bank-fixed effects & Yes & Yes & Yes & Yes & Yes & Yes \\
\hline Time-fixed effects & Yes & Yes & Yes & Yes & Yes & Yes \\
\hline $\bar{R}^{2}$ & 0.027 & 0.025 & 0.060 & 0.009 & -0.007 & -0.004 \\
\hline $\bar{R}_{\text {within }}^{2}$ & 0.006 & 0.003 & 0.022 & 0.007 & 0.003 & -0.000 \\
\hline No. of obs & 6358 & 8690 & 3209 & 4636 & 6358 & 8690 \\
\hline
\end{tabular}

This table shows regression results when alternative measures for the change in exposure are used as dependent variable. $\Delta \operatorname{Exp}_{i, s, t}^{E x t}$ stands for the extensive change in the sovereign exposure, being 1,0 , or -1 , respectively, for an increase, no change, or decrease in the size of the exposure. $\Delta \operatorname{Exp}_{i, s, t}^{B}$ is the within-exposure change. $\Delta \operatorname{Exp}_{i, s, t}^{C}$ measures changes to the weight of an exposure. ${ }^{*}$ significant at 10 percent; ${ }^{* *}$ significant at 5 percent; ${ }^{* * *}$ significant at 1 percent. t-statistics between brackets.

Columns (3) and (4) show the result when using logarithmic differences to measure the change in sovereign exposure of each bank, $\Delta \operatorname{Exp}_{i, s, t}^{B}$, (similar to, e.g., Altavilla et al. 2017). In both periods, the coefficients on the Sharpe ratio are not significant. As this measure equally weights increases in small and large exposures, these results suggest that banks pay less attention to the risk-return dimension for small exposures. However, we do see that, similar to columns (1) and (2), the sovereign CDS spread is positive and significant in the period 2011-2014, whereas between 2015-2018, the coefficient is negative and significant, indicating that banks were investing in higher risk sovereigns during the sovereign debt crisis and were divesting from these sovereign bonds afterwards. This result is consistent with a build-up of high-risk sovereign bonds, for instance, due to a search for yield, in the first period, and de-risking in the second period.

Finally, columns (5) and (6) show results when using the change in weight, $\Delta \operatorname{Exp}_{i, s, t}^{C}$, as the dependent variable. Similar to Table 3, we find that the Sharpe ratio is not significant in the period 2011-2014, but does become significant in the period 2015-2018.

\subsection{Impact of Accounting Rules}

Another concern is that our results might be driven by a mechanical effect due to accounting rules forcing banks to adjust the value of sovereign holdings when the fair value has increased. Since the EBA data only contains the Euro value of each sovereign exposure, it is not clear whether an increase in the exposure is driven by an increase in fair value or whether the bank has actually purchased bonds. To check whether this matters, we turn to the transparency exercises of 2016, 2017, and 2018, where the EBA provides data on the accounting classification of the sovereign bond holdings. Exposures are classified as either 'Held for trading', 'Designated at Fair Value through P\&L', 'Available-for-sale', 'Loans and receivables', or 'Held-to-maturity investments'. The first three categories should be accounted at fair value (FV), whereas the last two categories are booked at amortised 
cost (AC). For each bank, we average over the available periods the percentage of the portfolio that is allocated at amortised cost. Based on these averages, we construct a dummy capturing banks that have above-median amortised cost accounting, and interact the dummy with the Sharpe ratio. Table 7 shows that our main result holds, as the Sharpe ratio is insignificant in the first period but is positive and statistically significant in the second period. Moreover, the interactions of the Sharpe ratio with the dummy capturing the accounting differences between banks are not significant, implying that the findings are not driven by accounting rules and the associated repricing of the sovereign exposures.

Table 7. Robustness: model by accounting portfolio.

\begin{tabular}{|c|c|c|}
\hline $\begin{array}{c}\text { Column } \\
\text { Dependent Variable }\end{array}$ & \multicolumn{2}{|c|}{$\Delta \operatorname{Exp}_{i, s, t}^{A}$} \\
\hline Years & 2011-2014 & 2015-2018 \\
\hline Sharpe ratio & $\begin{array}{c}0.019 \\
(0.615)\end{array}$ & $\begin{array}{l}0.066^{* *} \\
(2.464)\end{array}$ \\
\hline Above median $\mathrm{AC}^{*}$ Sharpe ratio & $\begin{array}{l}-0.015 \\
(-0.441)\end{array}$ & $\begin{array}{c}0.029 \\
(1.006)\end{array}$ \\
\hline $\mathrm{CDS}_{\text {Sovereign }}$ & $\begin{array}{l}0.007^{*} \\
(1.924)\end{array}$ & $\begin{array}{c}0.019 \\
(1.387)\end{array}$ \\
\hline Above median $\mathrm{AC}^{*} \mathrm{CDS}_{\text {Sovereign }}$ & $\begin{array}{l}-0.001 \\
(-0.757)\end{array}$ & $\begin{array}{l}-0.002 \\
(-0.208)\end{array}$ \\
\hline Home & $\begin{array}{l}1.952 * * * \\
(4.315)\end{array}$ & $\begin{array}{l}-0.401 \\
(-1.201)\end{array}$ \\
\hline Bank controls & Yes & Yes \\
\hline Country-fixed effects & Yes & Yes \\
\hline Bank-fixed effects & Yes & Yes \\
\hline Time-fixed effects & Yes & Yes \\
\hline $\bar{R}^{2}$ & 0.055 & 0.018 \\
\hline $\bar{R}_{\text {within }}^{2}$ & 0.035 & 0.004 \\
\hline No. of obs & 6182 & 8360 \\
\hline
\end{tabular}

\subsection{Risk-Return Considerations during Periods of Large Issuance by the Home Sovereign}

A final concern is that some countries may have issued large amounts of new debt and that domestic banks, especially, would be subject to moral suasion, which may affect these banks' decision to purchase sovereign bonds. Since we split our sample in two periods, this might not fully capture such periods where moral suasion might materialize. To alleviate this concern, we follow Ongena et al. (2019), and define periods in which moral suasion could be at play. To do so, we collect, from Refinitiv, the ISIN codes of all bonds that are issued by each sovereign, and for each ISIN code, we obtain the Euro amount outstanding on every day in our sample period. This approach allows us to capture both the issuances and roll-overs made by sovereigns as increases of the amount outstanding for a specific ISIN. The issuances and roll-over amounts made in every semi-annual period are then summed over all ISINs to obtain the total amount of bonds issued or rolled-over by the sovereign in this period. ${ }^{12}$

We define a Large Issuance as the top quartile of issuances relative to the total outstanding debt in our sample period, and include an interaction effect, Home $\times$ Large Issuance, which captures the periods in which home sovereigns have a large issuance of bonds. Table 8 shows the results when we add this variable to the regressions. We observe that the variable Home $\times$ Large Issuance is positive in both periods, consistent with the moral suasion story, albeit not statistically significant. The results for the Sharpe ratio and its components are robust to the inclusion of this variable, as the coefficients on the Sharpe ratio remain positive and significant. 
Table 8. Robustness: largest home country issuances in both subperiods.

\begin{tabular}{|c|c|c|c|c|c|c|c|c|c|}
\hline $\begin{array}{c}\text { Column } \\
\text { Dependent Variable }\end{array}$ & $\begin{array}{c}\text { (1) } \\
\Delta \operatorname{Exp}_{i, s, t}^{A}\end{array}$ & $\begin{array}{c}(2) \\
\Delta \operatorname{Exp}_{i, s, t}^{A}\end{array}$ & $\begin{array}{c}\text { (3) } \\
\Delta \operatorname{Exp}_{i, s, t}^{A}\end{array}$ & $\begin{array}{c}\text { (4) } \\
\Delta \operatorname{Exp}_{i, s, t}^{A}\end{array}$ & $\begin{array}{c}(5) \\
\Delta \operatorname{Exp}_{i, s, t}^{A}\end{array}$ & $\begin{array}{c}\text { (6) } \\
\Delta \operatorname{Exp}_{i, s, t}^{A}\end{array}$ & $\begin{array}{c}(7) \\
\Delta \operatorname{Exp}_{i, s, t}^{A}\end{array}$ & $\begin{array}{c}\text { (8) } \\
\Delta \operatorname{Exp}_{i, s, t}^{A}\end{array}$ & $\begin{array}{c}\text { (9) } \\
\Delta \operatorname{Exp}_{i, s, t}^{A}\end{array}$ \\
\hline \multicolumn{10}{|c|}{ Panel A: July 2011-December 2014} \\
\hline Home & $\begin{array}{c}1.608^{* * *} \\
(2.670)\end{array}$ & $\begin{array}{c}1.540 * * * \\
(2.668)\end{array}$ & & $\begin{array}{c}1.607^{* * *} \\
(2.670)\end{array}$ & $\begin{array}{c}1.540 * * * \\
(2.669)\end{array}$ & & $\begin{array}{c}1.608^{* * *} \\
(2.671)\end{array}$ & $\begin{array}{c}1.541 * * * \\
(2.669)\end{array}$ & \\
\hline Large Issuance & $\begin{array}{c}0.011 \\
(0.198)\end{array}$ & $\begin{array}{c}0.021 \\
(0.390)\end{array}$ & $\begin{array}{l}0.029 \\
(0.494)\end{array}$ & $\begin{array}{c}0.006 \\
(0.114)\end{array}$ & $\begin{array}{c}0.018 \\
(0.312)\end{array}$ & $\begin{array}{c}0.022 \\
(0.377)\end{array}$ & $\begin{array}{c}0.013 \\
(0.240)\end{array}$ & $\begin{array}{c}0.024 \\
(0.438)\end{array}$ & $\begin{array}{c}0.034 \\
(0.587)\end{array}$ \\
\hline Home*Large Issuance & $\begin{array}{c}0.904 \\
(1.009)\end{array}$ & $\begin{array}{l}1.006 \\
(1.170)\end{array}$ & $\begin{array}{l}1.236 \\
(1.239)\end{array}$ & $\begin{array}{c}0.904 \\
(1.010)\end{array}$ & $\begin{array}{c}1.005 \\
(1.170)\end{array}$ & $\begin{array}{c}1.234 \\
(1.238)\end{array}$ & $\begin{array}{c}0.906 \\
(1.013)\end{array}$ & $\begin{array}{c}1.009 \\
(1.175)\end{array}$ & $\begin{array}{l}1.250 \\
(1.256)\end{array}$ \\
\hline Sharpe ratio & $\begin{array}{l}0.013 \\
(0.506)\end{array}$ & $\begin{array}{c}0.015 \\
(0.606)\end{array}$ & $\begin{array}{c}0.027 \\
(0.980)\end{array}$ & & & & & & \\
\hline Real. return & & & & $\begin{array}{c}0.005 \\
(1.512)\end{array}$ & $\begin{array}{c}0.005 \\
(1.487)\end{array}$ & $\begin{array}{c}0.005 \\
(1.597)\end{array}$ & & & \\
\hline Real. volatility & & & & $\begin{array}{l}-0.001 \\
(-0.312)\end{array}$ & $\begin{array}{l}-0.001 \\
(-0.317)\end{array}$ & $\begin{array}{l}-0.001 \\
(-0.341)\end{array}$ & & & \\
\hline YTM & & & & & & & $\begin{array}{c}0.021 \\
(0.599)\end{array}$ & $\begin{array}{c}0.027 \\
(0.756)\end{array}$ & $\begin{array}{c}0.054 \\
(1.361)\end{array}$ \\
\hline $\mathrm{CDS}_{\text {Sovereign }}$ & $\begin{array}{l}0.007^{*} \\
(1.764)\end{array}$ & $\begin{array}{l}0.007 * \\
(1.784)\end{array}$ & $\begin{array}{c}0.010 * * * \\
(3.136)\end{array}$ & $\begin{array}{l}-0.001 \\
(-0.086)\end{array}$ & $\begin{array}{l}-0.000 \\
(-0.015)\end{array}$ & $\begin{array}{c}0.003 \\
(0.568)\end{array}$ & $\begin{array}{l}0.007^{* *} \\
(2.064)\end{array}$ & $\begin{array}{l}0.007^{* * *} \\
(2.116)\end{array}$ & $\begin{array}{c}0.011^{* * *} \\
(4.101)\end{array}$ \\
\hline Bank controls & Yes & - & Yes & Yes & - & Yes & Yes & - & Yes \\
\hline Country-fixed effects & Yes & Yes & - & Yes & Yes & - & Yes & Yes & - \\
\hline Bank-fixed effects & Yes & - & - & Yes & - & - & Yes & - & - \\
\hline Time-fixed effects & Yes & - & Yes & Yes & - & Yes & Yes & - & Yes \\
\hline Bank-Time-fixed effects & - & Yes & - & - & Yes & - & - & Yes & - \\
\hline Bank-Country-fixed effects & - & - & Yes & - & - & Yes & - & - & Yes \\
\hline $\bar{R}^{2}$ & 0.056 & 0.073 & 0.049 & 0.056 & 0.073 & 0.049 & 0.056 & 0.073 & 0.050 \\
\hline $\bar{R}_{\text {within }}^{2}$ & 0.037 & 0.036 & 0.008 & 0.037 & 0.036 & 0.008 & 0.037 & 0.036 & 0.008 \\
\hline No. of obs & 6182 & 6358 & 5808 & 6182 & 6358 & 5808 & 6182 & 6358 & 5808 \\
\hline \multicolumn{10}{|c|}{ Panel B: January 2015-June 2018} \\
\hline Home & $\begin{array}{l}-0.483 \\
(-1.352)\end{array}$ & $\begin{array}{l}-0.423 \\
(-1.229)\end{array}$ & & $\begin{array}{c}-0.486 \\
(-1.360)\end{array}$ & $\begin{array}{c}-0.426 \\
(-1.238)\end{array}$ & & $\begin{array}{l}-0.487 \\
(-1.359)\end{array}$ & $\begin{array}{l}-0.427 \\
(-1.237)\end{array}$ & \\
\hline Large Issuance & $\begin{array}{c}0.067 \\
(1.449)\end{array}$ & $\begin{array}{l}0.081^{*} \\
(1.732)\end{array}$ & $\begin{array}{c}0.057 \\
(1.186)\end{array}$ & $\begin{array}{c}0.061 \\
(1.316)\end{array}$ & $\begin{array}{c}0.073 \\
(1.556)\end{array}$ & $\begin{array}{c}0.049 \\
(1.016)\end{array}$ & $\begin{array}{c}0.023 \\
(0.516)\end{array}$ & $\begin{array}{c}0.035 \\
(0.764)\end{array}$ & $\begin{array}{c}0.009 \\
(0.205)\end{array}$ \\
\hline Home*Large Issuance & $\begin{array}{c}0.560 \\
(0.569)\end{array}$ & $\begin{array}{c}0.495 \\
(0.508)\end{array}$ & $\begin{array}{c}0.693 \\
(0.602)\end{array}$ & $\begin{array}{c}0.584 \\
(0.595)\end{array}$ & $\begin{array}{c}0.520 \\
(0.535)\end{array}$ & $\begin{array}{c}0.726 \\
(0.631)\end{array}$ & $\begin{array}{c}0.567 \\
(0.577)\end{array}$ & $\begin{array}{c}0.503 \\
(0.517)\end{array}$ & $\begin{array}{c}0.724 \\
(0.628)\end{array}$ \\
\hline Sharpe ratio & $\begin{array}{c}0.087^{* * *} \\
(4.011)\end{array}$ & $\begin{array}{c}0.092^{* * *} \\
(4.353)\end{array}$ & $\begin{array}{c}0.087^{* * * *} \\
(3.924)\end{array}$ & & & & & & \\
\hline Real. return & & & & $\begin{array}{c}0.008^{* * *} \\
(3.796)\end{array}$ & $\begin{array}{c}0.008^{* * *} \\
(3.920)\end{array}$ & $\begin{array}{c}0.008^{* * *} \\
(3.695)\end{array}$ & & & \\
\hline Real. volatility & & & & $\begin{array}{c}-0.007 \\
(-1.319)\end{array}$ & $\begin{array}{c}-0.007 \\
(-1.338)\end{array}$ & $\begin{array}{c}-0.008 \\
(-1.358)\end{array}$ & & & \\
\hline YTM & & & & & & & $\begin{array}{c}0.136^{* *} \\
(2.029)\end{array}$ & $\begin{array}{c}0.136^{* *} \\
(2.068)\end{array}$ & $\begin{array}{c}0.161 * * \\
(2.405)\end{array}$ \\
\hline $\mathrm{CDS}_{\text {Sovereign }}$ & $\begin{array}{c}0.026^{* *} \\
(2.024)\end{array}$ & $\begin{array}{c}0.027^{* *} \\
(2.153)\end{array}$ & $\begin{array}{c}0.013 \\
(1.332)\end{array}$ & $\begin{array}{c}0.081^{* *} \\
(2.289)\end{array}$ & $\begin{array}{c}0.082 * * \\
(2.383)\end{array}$ & $\begin{array}{l}0.068^{*} \\
(1.911)\end{array}$ & $\begin{array}{c}-0.031 \\
(-1.462)\end{array}$ & $\begin{array}{c}-0.031 \\
(-1.431)\end{array}$ & $\begin{array}{c}-0.054^{* * * *} \\
(-2.798)\end{array}$ \\
\hline Bank controls & Yes & - & Yes & Yes & - & Yes & Yes & - & Yes \\
\hline Country-fixed effects & Yes & Yes & - & Yes & Yes & - & Yes & Yes & - \\
\hline Bank-fixed effects & Yes & - & - & Yes & - & - & Yes & - & - \\
\hline Time-fixed effects & Yes & - & Yes & Yes & - & Yes & Yes & - & Yes \\
\hline Bank-Time-fixed effects & - & Yes & - & - & Yes & - & - & Yes & - \\
\hline Bank-Country-fixed effects & - & - & Yes & - & - & Yes & - & - & Yes \\
\hline $\bar{R}^{2}$ & 0.019 & 0.037 & 0.020 & 0.018 & 0.037 & 0.020 & 0.018 & 0.036 & 0.019 \\
\hline $\bar{R}_{\text {within }}^{2}$ & 0.004 & 0.003 & 0.003 & 0.004 & 0.003 & 0.002 & 0.003 & 0.002 & 0.001 \\
\hline No. of obs & 8360 & 8690 & 8008 & 8360 & 8690 & 8008 & 8360 & 8690 & 8008 \\
\hline
\end{tabular}

This table shows regression results for the model extended with a dummy that is 1 in periods when the home country issued an amount of new debt that is in the top quantile in both sample periods. The dependent variable is the within-sovereign portfolio change or the percentage change in a sovereign exposure, relative to the size of the total sovereign debt portfolio. * significant at 10 percent; ${ }^{* *}$ significant at 5 percent; ${ }^{* * *}$ significant at 1 percent. t-statistics between brackets.

\section{Conclusions}

In this paper, we investigate whether or not observed changes in the composition of the sovereign bond portfolios of European banks are determined by a risk-return trade-off in the period following the sovereign debt crisis. Banks have been shown to disproportionately invest in bonds issued by their domestic sovereign before and during the sovereign debt crisis, causing a bank-sovereign doom loop. Several motivations for such behavior have been demonstrated in the extant literature, such as searching for yields or moral suasion, which, from an investment perspective, all involve some degree of irrational behavior. However, since the sovereign debt crisis, regulators and supervisors have proposed approaches to tackle the sovereign-bank nexus, which may have changed banks' motives to invest in certain sovereign bonds, and force banks to return to 'rational' behavior, in which return and risk are balanced. 
We contribute to the literature by investigating the risk-return trade-off in the bank sovereign bond portfolios during and after the sovereign debt crisis. We use data from the stress tests and transparency exercises conducted by the EBA for a sample of 75 European banks. We consider the period 2011-2018 and split this in the period of the sovereign debt crisis, 2011-2014, and the period following the sovereign debt crisis, 2015-2018, characterized by decreasing bond yields caused by the ECB's accommodative monetary policy. Using the Sharpe ratio to capture the risk-return trade-off, we confirm the finding in the existing literature that banks were subject to moral suasion as they predominantly invested in bonds of their home sovereign. Our main new result is that, in the period 2015-2018, banks' investments and divestments of sovereign bonds are characterized by sound risk-return considerations, suggesting a lessening of the doom loop. We split the banks and their investments into (non-)GIPS countries, and find that the post-sovereign debt crisis result is mainly driven by banks in the non-GIPS countries. Sovereign bond investments from banks in the non-GIPS countries load significantly and positively on the Sharpe ratios of both GIPS and non-GIPS sovereign bonds after the sovereign debt crisis, but not before. Banks outside of the GIPS region have reverted to behavior that should lead to a diversified sovereign exposures portfolio, which is the outcome desired by the supervisory authorities. GIPS country banks are not found to exhibit a sound risk-return trade-off in their sovereign securities investments, nor do they avoid securities of riskier countries, in the period following the sovereign debt crisis. In other words, those banks which were already most exposed to the bank-sovereign doom loop show no signs of improvement. Our results are robust to using different measures of exposures, different measures of risk-return trade-off, and taking into account different accounting treatments.

These findings have implications for policy initiatives targeting sovereign bond holdings by European banks. Since our results confirm previous evidence that banks can be subject to moral suasion or excessive risk taking in stress periods, regulators need to monitor the build-up of sovereign exposures, especially in more turbulent periods. For example, during the COVID-19 crisis, some banks are reported to have, again, increased their exposures to their home sovereigns, in what the 'Wall Street Journal' dubbed 'Setting up the Doom Loop Sequel in Europe'. Potential solutions consist in imposing exposure limits on the banks' holdings of sovereign bonds or subjecting these exposures to capital requirements. A more fundamental solution would be that banks have the option to invest in Eurobonds as a safe asset. Nevertheless, our findings for the 2015-2018 period imply that banks have started diversifying their sovereign bond holdings away from the domestic and into sovereigns with a better risk-return trade-off, at least for banks outside the GIPS region. If there is no visible improvement in the risk-return behavior of GIPS banks in their sovereign investments, we can predict that once the public-sector purchase program of the ECB will end, the calls for regulatory measures to curb excessive sovereign exposures will regain prominence.

Author Contributions: All authors contributed equally to this work. All authors have read and agreed to the published version of the manuscript.

Funding: This research received no external funding.

Institutional Review Board Statement: Not applicable.

Informed Consent Statement: Not applicable.

Data Availability Statement: Data available upon request from the corresponding author.

Acknowledgments: We thank Ralph de Haas, Klaas Mulier, Kris Boudt, Koen Inghelbrecht, the participants at the 2020 Meeting of World Finance Conference, the EFMA Annual Meeting, and Ghent University Banking and Finance seminar for their comments and suggestions. All remaining errors are our own.

Conflicts of Interest: The authors declare no conflict of interest. 


\section{Appendix A}

Table A1. Results of Table 3 with bank control variables.

\begin{tabular}{|c|c|c|c|c|c|c|c|c|c|}
\hline $\begin{array}{c}\text { Column } \\
\text { Dependent Variable }\end{array}$ & $\begin{array}{c}\text { (1) } \\
\Delta \operatorname{Exp}_{i, s, t}^{A}\end{array}$ & $\begin{array}{c}(2) \\
\Delta \operatorname{Exp}_{i, s, t}^{A}\end{array}$ & $\begin{array}{c}(3) \\
\Delta \operatorname{Exp}_{i, s, t}^{A}\end{array}$ & $\begin{array}{c}(4) \\
\Delta \operatorname{Exp}_{i, s, t}^{A}\end{array}$ & $\begin{array}{c}(5) \\
\Delta \operatorname{Exp}_{i, s, t}^{A}\end{array}$ & $\begin{array}{c}\text { (6) } \\
\Delta \operatorname{Exp}_{i, s, t}^{A}\end{array}$ & $\begin{array}{c}(7) \\
\Delta \operatorname{Exp}_{i, s, t}^{A}\end{array}$ & $\begin{array}{c}\text { (8) } \\
\Delta \operatorname{Exp}_{i, s, t}^{A}\end{array}$ & $\begin{array}{c}\text { (9) } \\
\Delta \operatorname{Exp}_{i, s, t}^{A}\end{array}$ \\
\hline \multicolumn{10}{|c|}{ Panel A: July 2011-December 2014} \\
\hline Sharpe ratio & $\begin{array}{c}0.011 \\
(0.444)\end{array}$ & $\begin{array}{c}0.013 \\
(0.528)\end{array}$ & $\begin{array}{c}0.026 \\
(0.928)\end{array}$ & & & & & & \\
\hline Real. return & & & & $\begin{array}{c}0.005 \\
(1.536)\end{array}$ & $\begin{array}{c}0.005 \\
(1.516)\end{array}$ & $\begin{array}{l}0.005^{*} \\
(1.688)\end{array}$ & & & \\
\hline Real. volatility & & & & $\begin{array}{l}-0.001 \\
(-0.324)\end{array}$ & $\begin{array}{l}-0.001 \\
(-0.315)\end{array}$ & $\begin{array}{l}-0.001 \\
(-0.389)\end{array}$ & & & \\
\hline YTM & & & & & & & $\begin{array}{c}0.017 \\
(0.471)\end{array}$ & $\begin{array}{c}0.021 \\
(0.603)\end{array}$ & $\begin{array}{c}0.045 \\
(1.139)\end{array}$ \\
\hline $\mathrm{CDS}_{\text {Sovereign }}$ & $\begin{array}{l}0.007^{*} \\
(1.750)\end{array}$ & $\begin{array}{l}0.007^{*} \\
(1.755)\end{array}$ & $\begin{array}{c}0.010^{* * *} \\
(3.159)\end{array}$ & $\begin{array}{l}-0.001 \\
(-0.122)\end{array}$ & $\begin{array}{l}-0.000 \\
(-0.067)\end{array}$ & $\begin{array}{c}0.003 \\
(0.506)\end{array}$ & $\begin{array}{l}0.007^{* *} \\
(2.024)\end{array}$ & $\begin{array}{l}0.007^{* *} \\
(2.054)\end{array}$ & $\begin{array}{l}0.011^{* * *} \\
(4.107)\end{array}$ \\
\hline Home & $\begin{array}{c}1.948^{* * *} \\
(4.299)\end{array}$ & $\begin{array}{l}1.915^{* * *} \\
(4.398)\end{array}$ & & $\begin{array}{l}1.947^{* * *} \\
(4.300)\end{array}$ & $\begin{array}{l}1.915^{* * *} \\
(4.400)\end{array}$ & & $\begin{array}{c}1.949^{* * *} \\
(4.302)\end{array}$ & $\begin{array}{l}1.917^{* * *} \\
(4.402)\end{array}$ & \\
\hline $\operatorname{Ln}(\mathrm{TA})_{t-1}$ & $\begin{array}{l}-0.368 \\
(-0.988)\end{array}$ & & $\begin{array}{l}-0.368 \\
(-1.077)\end{array}$ & $\begin{array}{l}-0.368 \\
(-0.988)\end{array}$ & & $\begin{array}{l}-0.368 \\
(-1.078)\end{array}$ & $\begin{array}{l}-0.368 \\
(-0.988)\end{array}$ & & $\begin{array}{l}-0.368 \\
(-1.079)\end{array}$ \\
\hline Equity/Total Assets ${ }_{t-1}$ & $\begin{array}{c}0.054 \\
(1.445)\end{array}$ & & $\begin{array}{l}0.054 * \\
(1.685)\end{array}$ & $\begin{array}{c}0.054 \\
(1.447)\end{array}$ & & $\begin{array}{l}0.054^{*} \\
(1.688)\end{array}$ & $\begin{array}{c}0.054 \\
(1.445)\end{array}$ & & $\begin{array}{l}0.054 * \\
(1.684)\end{array}$ \\
\hline NPL/Loans $t_{t-1}$ & $\begin{array}{l}-0.018^{*} \\
(-1.846)\end{array}$ & & $\begin{array}{l}-0.018^{*} \\
(-1.912)\end{array}$ & $\begin{array}{l}-0.018^{*} \\
(-1.846)\end{array}$ & & $\begin{array}{l}-0.018^{*} \\
(-1.912)\end{array}$ & $\begin{array}{l}-0.018^{*} \\
(-1.846)\end{array}$ & & $\begin{array}{l}-0.018^{*} \\
(-1.912)\end{array}$ \\
\hline Loans/Deposits ${ }_{t-1}$ & $\begin{array}{c}0.005 \\
(1.546)\end{array}$ & & $\begin{array}{c}0.005 \\
(1.582)\end{array}$ & $\begin{array}{c}0.005 \\
(1.546)\end{array}$ & & $\begin{array}{c}0.005 \\
(1.583)\end{array}$ & $\begin{array}{c}0.005 \\
(1.546)\end{array}$ & & $\begin{array}{c}0.005 \\
(1.581)\end{array}$ \\
\hline Cash/Total Assets ${ }_{t-1}$ & $\begin{array}{l}0.051^{* *} \\
(2.526)\end{array}$ & & $\begin{array}{l}0.051 * * \\
(2.495)\end{array}$ & $\begin{array}{l}0.051 \text { ** } \\
(2.526)\end{array}$ & & $\begin{array}{l}0.051^{* *} \\
(2.496)\end{array}$ & $\begin{array}{l}0.051^{* *} \\
(2.526)\end{array}$ & & $\begin{array}{l}0.051 \text { ** } \\
(2.495)\end{array}$ \\
\hline Pre-tax $\mathrm{ROA}_{t-1}$ & $\begin{array}{c}0.001 \\
(0.015)\end{array}$ & & $\begin{array}{c}0.001 \\
(0.016)\end{array}$ & $\begin{array}{c}0.001 \\
(0.015)\end{array}$ & & $\begin{array}{c}0.001 \\
(0.016)\end{array}$ & $\begin{array}{c}0.001 \\
(0.015)\end{array}$ & & $\begin{array}{c}0.001 \\
(0.016)\end{array}$ \\
\hline Country-fixed effects & Yes & Yes & - & Yes & Yes & - & Yes & Yes & - \\
\hline Bank-fixed effects & Yes & - & - & Yes & - & - & Yes & - & - \\
\hline Time-fixed effects & Yes & - & Yes & Yes & - & Yes & Yes & - & Yes \\
\hline Bank-Time-fixed effects & - & Yes & - & - & Yes & - & - & Yes & - \\
\hline Bank-Country-fixed effects & - & - & Yes & - & - & Yes & - & - & Yes \\
\hline $\bar{R}^{2}$ & 0.055 & 0.071 & 0.046 & 0.055 & 0.071 & 0.046 & 0.055 & 0.071 & 0.046 \\
\hline $\bar{R}_{\text {within }}^{2}$ & 0.035 & 0.034 & 0.004 & 0.035 & 0.034 & 0.004 & 0.035 & 0.034 & 0.004 \\
\hline No. of obs & 6182 & 6358 & 5808 & 6182 & 6358 & 5808 & 6182 & 6358 & 5808 \\
\hline \multicolumn{10}{|c|}{ Panel B: January 2015-June 2018} \\
\hline Sharpe ratio & $\begin{array}{l}0.081 * * * \\
(3.781)\end{array}$ & $\begin{array}{c}0.085^{* * *} \\
(4.095)\end{array}$ & $\begin{array}{c}0.082^{* * *} \\
(3.778)\end{array}$ & & & & & & \\
\hline Real. return & & & & $\begin{array}{c}0.007^{* * *} \\
(3.487)\end{array}$ & $\begin{array}{l}0.007^{* * *} \\
(3.594)\end{array}$ & $\begin{array}{l}0.007^{* * *} \\
(3.476)\end{array}$ & & & \\
\hline Real. volatility & & & & $\begin{array}{l}-0.006 \\
(-1.128)\end{array}$ & $\begin{array}{l}-0.006 \\
(-1.132)\end{array}$ & $\begin{array}{l}-0.007 \\
(-1.193)\end{array}$ & & & \\
\hline YTM & & & & & & & $\begin{array}{c}0.133 * * \\
(1.988)\end{array}$ & $\begin{array}{l}0.133 * * \\
(2.024)\end{array}$ & $\begin{array}{c}0.157^{* *} \\
(2.359)\end{array}$ \\
\hline $\mathrm{CDS}_{\text {Sovereign }}$ & $\begin{array}{c}0.018 \\
(1.494)\end{array}$ & $\begin{array}{c}0.019 \\
(1.568)\end{array}$ & $\begin{array}{c}0.007 \\
(0.711)\end{array}$ & $\begin{array}{l}0.067^{*} \\
(1.934)\end{array}$ & $\begin{array}{c}0.067^{* *} \\
(1.993)\end{array}$ & $\begin{array}{c}0.055 \\
(1.619)\end{array}$ & $\begin{array}{c}-0.034 \\
(-1.600)\end{array}$ & $\begin{array}{l}-0.034 \\
(-1.584)\end{array}$ & $\begin{array}{l}-0.055^{* * *} \\
(-2.875)\end{array}$ \\
\hline Home & $\begin{array}{l}-0.400 \\
(-1.199)\end{array}$ & $\begin{array}{l}-0.351 \\
(-1.090)\end{array}$ & & $\begin{array}{l}-0.400 \\
(-1.197)\end{array}$ & $\begin{array}{l}-0.351 \\
(-1.088)\end{array}$ & & $\begin{array}{l}-0.402 \\
(-1.204)\end{array}$ & $\begin{array}{l}-0.354 \\
(-1.096)\end{array}$ & \\
\hline $\operatorname{Ln}(\mathrm{TA})_{t-1}$ & $\begin{array}{l}-0.987^{* *} \\
(-2.550)\end{array}$ & & $\begin{array}{l}-0.987^{* *} \\
(-2.569)\end{array}$ & $\begin{array}{l}-0.987^{* *} \\
(-2.550)\end{array}$ & & $\begin{array}{l}-0.987^{* *} \\
(-2.571)\end{array}$ & $\begin{array}{l}-0.987^{* *} \\
(-2.550)\end{array}$ & & $\begin{array}{l}-0.987^{* *} \\
(-2.571)\end{array}$ \\
\hline Equity/Total Assets t-1 $_{t}$ & $\begin{array}{l}-0.049 \\
(-0.848)\end{array}$ & & $\begin{array}{l}-0.049 \\
(-0.860)\end{array}$ & $\begin{array}{l}-0.049 \\
(-0.848)\end{array}$ & & $\begin{array}{l}-0.049 \\
(-0.861)\end{array}$ & $\begin{array}{l}-0.049 \\
(-0.847)\end{array}$ & & $\begin{array}{l}-0.049 \\
(-0.860)\end{array}$ \\
\hline NPL/Loans $t_{t-1}$ & $\begin{array}{l}-0.005 \\
(-0.761)\end{array}$ & & $\begin{array}{l}-0.005 \\
(-0.787)\end{array}$ & $\begin{array}{l}-0.005 \\
(-0.761)\end{array}$ & & $\begin{array}{l}-0.005 \\
(-0.787)\end{array}$ & $\begin{array}{l}-0.005 \\
(-0.760)\end{array}$ & & $\begin{array}{l}-0.005 \\
(-0.786)\end{array}$ \\
\hline Loans/Deposits $_{t-1}$ & $\begin{array}{c}0.000 \\
(0.186)\end{array}$ & & $\begin{array}{c}0.000 \\
(0.180)\end{array}$ & $\begin{array}{c}0.000 \\
(0.186)\end{array}$ & & $\begin{array}{c}0.000 \\
(0.180)\end{array}$ & $\begin{array}{c}0.000 \\
(0.186)\end{array}$ & & $\begin{array}{c}0.000 \\
(0.180)\end{array}$ \\
\hline Cash/Total Assets ${ }_{t-1}$ & $\begin{array}{c}0.011 \\
(0.986)\end{array}$ & & $\begin{array}{c}0.011 \\
(1.000)\end{array}$ & $\begin{array}{c}0.011 \\
(0.985)\end{array}$ & & $\begin{array}{c}0.011 \\
(0.999)\end{array}$ & $\begin{array}{c}0.011 \\
(0.984)\end{array}$ & & $\begin{array}{c}0.011 \\
(0.997)\end{array}$ \\
\hline Pre-tax $\mathrm{ROA}_{t-1}$ & $\begin{array}{c}0.065 \\
(1.622)\end{array}$ & & $\begin{array}{l}0.065^{*} \\
(1.731)\end{array}$ & $\begin{array}{c}0.065 \\
(1.623)\end{array}$ & & $\begin{array}{l}0.065^{*} \\
(1.735)\end{array}$ & $\begin{array}{c}0.065 \\
(1.619)\end{array}$ & & $\begin{array}{l}0.065^{*} \\
(1.732)\end{array}$ \\
\hline Country-fixed effects & Yes & Yes & - & Yes & Yes & - & Yes & Yes & - \\
\hline Bank-fixed effects & Yes & - & - & Yes & - & - & Yes & - & - \\
\hline Time-fixed effects & Yes & - & Yes & Yes & - & Yes & Yes & - & Yes \\
\hline Bank-Time-fixed effects & - & Yes & - & - & Yes & - & - & Yes & - \\
\hline Bank-Country-fixed effects & - & - & Yes & - & - & Yes & - & - & Yes \\
\hline $\bar{R}^{2}$ & 0.018 & 0.037 & 0.020 & 0.018 & 0.036 & 0.019 & 0.017 & 0.036 & 0.019 \\
\hline $\bar{R}_{\text {within }}^{2}$ & 0.004 & 0.003 & 0.002 & 0.003 & 0.002 & 0.002 & 0.003 & 0.002 & 0.001 \\
\hline No. of obs & 8360 & 8690 & 8008 & 8360 & 8690 & 8008 & 8360 & 8690 & 8008 \\
\hline
\end{tabular}

This table shows regression results of the model estimated in the sample periods from July 2011 until December 2014, and January 2015 until June 2018. * significant at 10 percent; ${ }^{* *}$ significant at 5 percent; ${ }^{* * *}$ significant at 1 percent. t-statistics between brackets. 
Table A2. Model by regional origination.

\begin{tabular}{|c|c|c|c|c|}
\hline $\begin{array}{c}\text { Column } \\
\text { Dependent Variable }\end{array}$ & $\begin{array}{c}\text { (1) } \\
\Delta \operatorname{Exp}_{i, s, t}^{A}\end{array}$ & $\begin{array}{c}(2) \\
\Delta \operatorname{Exp}_{i, s, t}^{A}\end{array}$ & $\begin{array}{c}(3) \\
\Delta \operatorname{Exp}_{i, s, t}^{A}\end{array}$ & $\begin{array}{c}(4) \\
\Delta \operatorname{Exp}_{i, s, t}^{A}\end{array}$ \\
\hline Years & 2011-2014 & 2015-2018 & 2011-2014 & 2015-2018 \\
\hline Sharpe ratio & $\begin{array}{c}0.014 \\
(0.603)\end{array}$ & $\begin{array}{l}0.031 * \\
(1.886)\end{array}$ & & \\
\hline $\mathrm{SOV}_{\text {GIPS }} \times$ Sharpe ratio & $\begin{array}{l}-0.013 \\
(-0.280)\end{array}$ & $\begin{array}{l}0.074^{* *} \\
(2.381)\end{array}$ & & \\
\hline BANK $_{\text {GIPS }} \times$ Sharpe ratio & $\begin{array}{l}-0.047^{*} \\
(-1.793)\end{array}$ & $\begin{array}{l}-0.015 \\
(-0.727)\end{array}$ & & \\
\hline $\mathrm{SOV}_{G I P S} \times \mathrm{BANK}_{\text {GIPS }} \times$ Sharpe ratio & $\begin{array}{l}0.204^{* *} \\
(2.161)\end{array}$ & $\begin{array}{l}-0.000 \\
(-0.005)\end{array}$ & & \\
\hline Real. return & & & $\begin{array}{l}-0.001 \\
(-0.510)\end{array}$ & $\begin{array}{c}0.004 \\
(1.605)\end{array}$ \\
\hline $\mathrm{SOV}_{\text {GIPS }} \times$ Real. return & & & $\begin{array}{c}0.002 \\
{[0.566]}\end{array}$ & $\begin{array}{c}0.000 \\
(0.020)\end{array}$ \\
\hline BANK $_{G I P S} \times$ Real. return & & & $\begin{array}{l}-0.005 \\
(-1.353)\end{array}$ & $\begin{array}{l}-0.004 \\
(-1.064)\end{array}$ \\
\hline $\mathrm{SOV}_{G I P S} \times \mathrm{BANK}_{G I P S} \times$ Real. return & & & $\begin{array}{c}0.008 \\
(1.632)\end{array}$ & $\begin{array}{c}0.000 \\
(0.068)\end{array}$ \\
\hline Real. volatility & & & $\begin{array}{c}0.002 \\
(0.925)\end{array}$ & $\begin{array}{c}0.000 \\
(0.009)\end{array}$ \\
\hline $\mathrm{SOV}_{G I P S} \times$ Real. volatility & & & $\begin{array}{l}-0.006 \\
(-1.489)\end{array}$ & $\begin{array}{l}-0.007 \\
(-0.871)\end{array}$ \\
\hline BANK $_{G I P S} \times$ Real. volatility & & & $\begin{array}{c}0.007 * * * \\
(2.606)\end{array}$ & $\begin{array}{l}-0.009 \\
(-1.038)\end{array}$ \\
\hline $\mathrm{SOV}_{\text {GIPS }} \times \mathrm{BANK}_{\text {GIPS }} \times$ Real. volatility & & & $\begin{array}{l}-0.012 \\
(-1.563)\end{array}$ & $\begin{array}{c}0.014 \\
(1.595)\end{array}$ \\
\hline $\mathrm{SOV}_{G I P S} \times \mathrm{BANK}_{G I P S}$ & $\begin{array}{c}0.186 \\
(1.269)\end{array}$ & $\begin{array}{l}0.539 * * * \\
(2.920)\end{array}$ & $\begin{array}{l}0.538 * * \\
(2.363)\end{array}$ & $\begin{array}{l}0.484^{* * *} \\
(2.806)\end{array}$ \\
\hline Bank controls & Yes & Yes & Yes & Yes \\
\hline Country-fixed effects & Yes & Yes & Yes & Yes \\
\hline Bank-fixed effects & Yes & Yes & Yes & Yes \\
\hline Time-fixed effects & Yes & Yes & Yes & Yes \\
\hline $\bar{R}^{2}$ & 0.035 & 0.013 & 0.034 & 0.012 \\
\hline $\bar{R}_{\text {within }}^{2}$ & 0.007 & 0.006 & 0.006 & 0.005 \\
\hline No. of obs & 5926 & 8002 & 5926 & 8002 \\
\hline
\end{tabular}

This table shows regression results for the model where the risk-return measures are interacted with dummies for the regional origination of both the sovereign exposure and the bank. The exposure to the home country is excluded. * significant at 10 percent; ${ }^{* *}$ significant at 5 percent; ${ }^{* *}$ significant at 1 percent. t-statistics between brackets.

\section{Notes}

1 Our sample contains countries outside the Euro Area, but these countries are also characterized by declining long-term interest rates over the 2015-2018 period, often related to asset purchase programs of their central banks.

2 The gross carrying amount is a combination of exposures appraised at either fair value (available-for-sale) or at amortised cost (hold-to-maturity). Since only a few exercises contain data detailing the level of assets in each category, we follow previous literature and assume that all exposures are reported at amortised cost (see, e.g., Altavilla et al. 2017; Buch et al. 2016). In Section 6, we test the validity of this assumption and find that the accounting treatment of the exposures has no significant impact on our results.

3 Ongena et al. (2019) measure the change in the holding of domestic debt as a percentage of the total debt issued by the domestic. As such, the authors focus on the distribution of owners of debt issued by a specific sovereign. In our paper, the interest is in the distribution of a specific bank's holdings over different sovereigns and we, therefore, weigh the change in the holding to the size of the bond portfolio of the bank instead.

4 We use logarithmic changes over percentage changes to avoid losing observations where an exposure is reduced to zero. 
5 Note that, unlike previous papers that have looked at, e.g., home bias (see e.g., De Marco et al. 2021; Horvath et al. 2015; Saka 2020), we do not consider the weight (level) of the exposure separately, as this mainly reflects previous choices regarding the build-up of exposures instead of new asset-allocation decisions.

6 The 10-year sovereign bond yields could not be obtained for Cyprus (CY), Estonia (EE), Latvia (LV), Luxembourg (LU), Slovenia (SI), and Croatia (HR). The list of countries that are included in our analysis consists of Austria (AT), Belgium (BE), Bulgaria (BG), Czech Republic (CZ), Denmark (DK), Finland (FI), France (FR), Germany (DE), Greece (GR), Hungary (HU), Ireland (IE), Italy (IT), Lithuania (LT), Malta (MT), the Netherlands (NL), Poland (PL), Portugal (PT), Romania (RO), Slovakia (SK), Spain (ES), Sweden (SE), and the United Kingdom (UK).

7 The zero-coupon bond price at $t-1$ is derived as $P_{s, t-1}=\frac{100}{\left(1+Y T M_{s, t-1}^{10 y}\right)^{10+\frac{1}{252}}}$.

8 In the original paper (Sharpe 1966), excess returns over the risk-free return are used. However, since a 10-year government bond yield is often used as the risk-free rate, we make an abstraction of this and work with raw instead of excess returns.

9 Since Mariathasan and Merrouche (2014) show that banks may use internal ratings to optimize, or even underestimate, their risk-weighted assets, we prefer the unweighted equity ratio (or leverage ratio) to the CET1/RWA ratio.

10 In all regressions, we include the bank control variables, but do not report them to make the tables easier to read. As can be seen in Table A1, most control variables are insignificant. In the second subperiod, it turns out that larger banks exhibit less investment activity in their sovereign portfolio.

11 The separate regression results can be found in Table A2.

12 Note that we deviate from Ongena et al. (2019), who use the amount of sovereign debt maturing each month to identify sovereign needs for issue and, from that, the moral suasion channel. We use actual issued bonds in each period, which we think are a more accurate measure of sovereign debt needs.

\section{References}

Acharya, Viral, Itamar Drechsler, and Philipp Schnabl. 2014. A Pyrrhic Victory? Bank Bailouts and Sovereign Credit Risk. The Journal of Finance 69: 2689-39. [CrossRef]

Acharya, Viral, and Sascha Steffen. 2015. The "greatest" carry trade ever? Understanding eurozone bank risks. Journal of Financial Economics 115: 215-36. [CrossRef]

Alogoskoufis, Spyros, and Sam Langfield. 2020. Regulating the doom loop. International Journal of Central Banking 16: $251-92$. http://dx.doi.org/10.2849/14299.

Altavilla, Carlo, Marco Pagano, and Saverio Simonelli. 2017. Bank Exposures and Sovereign Stress Transmission. Review of Finance 21: 2103-39. [CrossRef]

Altunbas, Yener, Leonardo Gambacorta, and David Marques-lbanez. 2012. Do bank characteristics influence the effect of monetary policy on bank risk? Economics Letters 117: 220-22. [CrossRef]

Bénassy-Quéré, Agnès, Markus Brunnermeier, Henrik Enderlein, Emmanuel Farhi, Marcel Fratzscher, Clemens Fuest, Pierre-Olivier Gourinchas, Philippe Martin, Jean Pisani-Ferry, Hélène Rey, and et al. 2018. Reconciling risk sharing with market discipline: A constructive approach to euro area reform. CEPR Policy Insight 91: 1-24.

Berger, Allen, and Christa Bouwman. 2013. How does capital affect bank performance during financial crises. Journal of Financial Economics 109: 146-76. [CrossRef]

Brunnermeier, Markus, Luis Garicano, Philip Lane, Marco Pagano, Ricardo Reis, Tano Santos, David Thesmar, Stijn Van Nieuwerburgh, and Dimitri Vayanos. 2016. The sovereign-bank diabolic loop and esbies. American Economic Review 106: 508-12. [CrossRef]

Bubeck, Johannes, Angela Maddaloni, and José Luis Peydró. 2020. Negative Monetary Policy Rates and Systemic Banks' Risk-Taking: Evidence from the Euro Area Securities Register. Journal of Money Credit and Banking 52: 197-231. [CrossRef]

Buch, Claudia, Michael Koetter, and Jana Ohls. 2016. Banks and sovereign risk: A granular view. Journal of Financial Stability 25: 1-15. [CrossRef]

Carpinelli, Luisa, and Matteo Crosignani. 2021. The design and transmission of central bank liquidity provisions. Journal of Financial Economics 141: 27-47. [CrossRef]

Caselli, Stefano, Gino Gandolfi, and Maria Gaia Soana. 2016. The Impact of Sovereign Rating News on European Banks. European Financial Management 22: 142-67. [CrossRef]

Coeurdacier, Nicolas, and Helene Rey. 2013. Home bias in open economy financial macroeconomics. Journal of Economic Literature 51: 63-115. [CrossRef]

Crosignani, Matteo, Miguel Faria-e Castro, and Luís Fonseca. 2020. The (Unintended?) consequences of the largest liquidity injection ever. Journal of Monetary Economics 112: 97-112. [CrossRef]

Daniel, Kent, Mark Grinblatt, Sheridan Titman, and Russ Wermers. 1997. Measuring Mutual Fund Performance with CharacteristicBase Benchmarks. Journal of Finance 52: 1035-58. [CrossRef]

De Bruyckere, Valerie, Maria Gerhardt, Glenn Schepens, and Rudi Vander Vennet. 2013. Bank/sovereign risk spillovers in the European debt crisis. Journal of Banking and Finance 37: 4793-809. [CrossRef]

De Marco, Filippo, and Marco Macchiavelli. 2016. The Political Origin of Home Bias: The Case of Europe. Finance and Economics Discussion Series 60: 1-46. [CrossRef] 
De Marco, Filippo, Marco Macchiavelli, and Rosen Valchev. 2021. Beyond Home Bias: International Portfolio Holdings and Information Heterogeneity. The Review of Financial Studies. [CrossRef]

Dermine, Jean. 2020. Banks' home bias in government bond holdings: Will banks in low-rated countries invest in European safe bonds (ESBies)? European Financial Management 26: 841-58. [CrossRef]

Enria, Andrea. 2019. Interview with Andrea Enria, Chair of the Supervisory Board of the ECB, conducted by Claire Jones on 13 March and published on 19 March 2019. Financial Times.

Enria, Andrea, Adam Farkas, and Lars Jul Overby. 2016. Sovereign Risk: Black Swans and White Elephants. European Economy 1: 51-71.

Farhi, Emmanuel, and Jean Tirole. 2018. Deadly embrace: Sovereign and financial balance sheets doom loops. Review of Economic Studies 85: 1781-23. [CrossRef]

Fontana, Alessandro, and Martin Scheicher. 2016. An analysis of euro area sovereign CDS and their relation with government bonds. Journal of Banking and Finance 62: 126-40. [CrossRef]

Fratzscher, Marcel, and Malte Rieth. 2019. Monetary Policy, Bank Bailouts and the Sovereign-bank Risk Nexus in the Euro Area. Review of Finance 23: 745-75. [CrossRef]

Gennaioli, Nicola, Alberto Martin, and Stefano Rossi. 2014. Sovereign default, domestic banks, and financial institutions. Journal of Finance 69: 819-66. [CrossRef]

Heider, Florian, Farzad Saidi, and Glenn Schepens. 2019. Life below Zero: Bank Lending under Negative Policy Rates. The Review of Financial Studies 32: 3728-61. [CrossRef]

Horvath, Balint L, Harry Huizinga, and Vasso Ioannidou. 2015. Determinants and Valuation Effects of the Home Bias in European Bankss Sovereign Debt Portfolios. CEPR Discussion Paper 10661: 1-40. [CrossRef]

Jiménez, Gabriel, Steven Ongena, José-Luis Peydró, and Jesús Saurina. 2014. Hazardous Times for Monetary Policy: What Do Twenty-Three Million Bank Loans Say About the Effects of Monetary Policy on Credit Risk-Taking? Econometrica 82: 463-505. [CrossRef]

Kacperczyk, Marcin, Clemens Sialm, and Lu Zheng. 2005. On the industry concentration of actively managed equity mutual funds. Journal of Finance 60: 1983-2011. [CrossRef]

Kirschenmann, Karolin, Josef Korte, and Sascha Steffen. 2020. A zero-risk weight channel of sovereign risk spillovers. Journal of Financial Stability 51: 100780. [CrossRef]

Lamers, Martien, Frederik Mergaerts, Elien Meuleman, and Rudi Vander Vennet. 2019. The Tradeoff between Monetary Policy and Bank Stability. International Journal of Central Banking 15: 1-42.

Lenarcic, Andreja, Dirk Mevis, and Dora Siklos. 2016. Tackling Sovereign Risk in European Banks. European Stability Mechanism Discussion Paper Series 1; Luxembourg: Tackling Sovereign Risk in European Banks, pp. 1-42. [CrossRef]

Leote de Carvalho, Raul, Patrick Dugnolle, Lu Xiao, and Pierre Moulin. 2014. Low-Risk Anomalies in Global Fixed Income: Evidence from Major Broad Markets. Journal of Fixed Income 23: 51-70. [CrossRef]

Mariathasan, Mike, and Ouarda Merrouche. 2014. The manipulation of basel risk-weights. Journal of Financial Intermediation 23: 300-21. [CrossRef]

Markowitz, Harry. 1952. Portfolio Selection. The Journal of Finance 7: 77-91. [CrossRef]

Ongena, Steven, Alexander Popov, and Neeltje Van Horen. 2019. The invisible hand of the government: Moral suasion during the European sovereign debt crisis. American Economic Journal: Macroeconomics 11: 346-79. [CrossRef]

Pilotte, Eugene, and Frederic Sterbenz. 2006. Sharpe and treynor ratios on treasury bonds. Journal of Business 79: 149-80. [CrossRef]

Saka, Orkun. 2020. Domestic Banks As Lightning Rods? Home Bias and Information during the Eurozone Crisis. Journal of Money, Credit and Banking 52: 273-305. [CrossRef]

Sharpe, William. 1966. Mutual Fund Performance. The Journal of Business 39: 119-38. [CrossRef]

Stângă, Irina. 2014. Bank bailouts and bank-sovereign risk contagion channels. Journal of International Money and Finance 48: 17-40. [CrossRef]

Vazquez, Francisco, and Pablo Federico. 2015. Bank funding structures and risk: Evidence from the global financial crisis. Journal of Banking and Finance 61: 1-14. [CrossRef]

Zaremba, Adam, and Anna Czapkiewicz. 2017. Digesting anomalies in emerging European markets: A comparison of factor pricing models. Emerging Markets Review 31: 1-15. [CrossRef] 